\title{
Natural groups and economic characteristics as driving forces of wage discrimination
}

\author{
Thorsten Chmura ${ }^{a}$, Sebastian J. Goerg ${ }^{\mathrm{b}, \mathrm{c}, *}$, Pia Weiss ${ }^{\mathrm{a}}$ \\ a Nottingham University, Business School, Wollaton road, NG8 1BB Nottingham, UK \\ ${ }^{\mathrm{b}}$ Florida State University, Department of Economics, 113 Collegiate Loop, Tallahassee, FL 32306-2180, United States \\ ${ }^{\mathrm{c}}$ Max Planck Institute for Research on Collective Goods, Bonn, Germany
}

\section{A R T I C L E I N F O}

Article history:

Received 28 May 2015

Accepted 6 April 2016

Available online 27 April 2016

JEL classification:

C91

J31

J71

M52

Keywords:

Wages

Discrimination

Social identity

Natural groups

Lab experiment

Gift-exchange

Migrant-workers

China

\begin{abstract}
A B S T R A C T
We investigate whether the origin of an employee provides different motives for wage discrimination in gift-exchange experiments with students and migrant workers in China. In a lab and an internet experiment, subjects in the role of employers can condition their wages on the employees' home provinces. The resulting systematic differences in wages can be linked to natural groups and economic characteristics of the provinces. In-group favoritism increases wages for employees who share the same origin as the employer, while an increased probability of being matched with an employee with a different ethnicity reduces wages. Furthermore, wages in the laboratory increase with the actual wage level in the employees' home province. Nevertheless, employees' effort is not influenced by these variables; only the wage paid in the experiment influences effort.
\end{abstract}

(c) 2016 Elsevier B.V. All rights reserved.

\section{Introduction}

This paper explores whether the origin of an employee provides different motives for wage discrimination. To this end, we conduct two stylized gift-exchange experiments with students and migrant workers in the PR China. Students in the role of employers can condition wages on the employees' origin, while students and migrant workers in the role of employees choose effort levels based on wages. We augment the collected datasets with complementary data on the characteristics of Chinese provinces. This combination of lab and field data demonstrates three separate, but simultaneously present, effects on wages levels: First, wages in the experiments are influenced by actual wage levels in employees' home provinces, second, in-group favoritism increases wages for employees with the same origin as the employer, and third, ethnic diversity in the employees' home provinces decreases wages.

Previous research has shown that discriminating behavior can be conditioned on such diverse characteristics as gender (e.g., Neumark et al., 1996; Kuhn and Shen, 2013), race (e.g., Bertrand and Mullainathan, 2007; Pager et al. 2009; Zussman, 2013), age (e.g., Büsch et al., 2009; Riach and Judith, 2010), and even beauty (e.g., Mobius and Rosenblat, 2006; Wilson and Eckel, 2006).

\footnotetext{
* Corresponding author at: Florida State University, Department of Economics, 113 Collegiate Loop, Tallahassee, FL 32306-2180, United States.

E-mail address: sgoerg@fsu.edu (S.J. Goerg).
} 
Several potential reasons for discriminating behavior have been identified in the economic literature. While discrimination can be taste-based (Becker, 1957), differential treatment in labor markets can also be based on economic reasoning and differences in the actual or expected productivity of workers (Phelps, 1972). Employers might even offer discriminating payment schemes for identical work to provide proper incentives within teams (Winter, 2004; Goerg et al., 2010). Furthermore, varying perceptions of fair-wages among otherwise identical workers can result in wage differences. Two workers with different reference groups will consider different wage levels as fair when the perception of what constitutes a fair wage depends on the wages paid to the workers in these reference groups (Akerlof and Yellen, 1990). A similar argument can be put forward based on efficiency wages: if workers from one group have worse outside options than the others they are willing to accept lower wages for the same work or the same wage for more work hours. Kuhn and Shen (2014) propose that this as an explanation why employers in the PR China prefer migrant workers over comparable local workers as they expect higher levels of work hours for the same wage.

A different kind of motivation for discrimination has been identified in the social psychology literature. Broad evidence shows that group identity may lead to the preferential treatment of in-group members and discrimination against outgroup individuals - not necessarily through hostility, but through indifference (Sherif et al. 1961; Tajfel and Turner, 1979; Halevy et al., 2008). In economics, Akerlof and Kranton (2000) introduced social identity as an important driver of economic behavior and proposed a utility function according to which individuals aim to behave appropriately given the social group to which they belong. ${ }^{1}$ As the group affiliation defines part of one's identity it also influences the behavior towards group members and the outside. Thus, identity can provide the microfoundation for the previously discussed taste-based discrimination (see Akerlof and Kranton, 2000, p. 732).

The importance of group affiliation has been demonstrated for naturally occurring groups defined by such diverse features as race (Fershtman and Gneezy, 2001; Chen et al., 2014), gender (Charness and Rustichini, 2011), army platoons (Goette et al., 2006) and city districts (Falk and Zehnder, 2013). Furthermore, even artificial groups generated with the minimal-group paradigm (Tajfel and Turner, 1979) lead to in-group favoritism with potentially increased cooperation in social dilemmas (Yamagishi and Kiyonari, 2000; Eckel and Grossman, 2005; Chen and Li, 2009) and more efficient coordination in the minimum effort game (Chen and Chen, 2011).

This paper contributions to the literature on natural identities and discrimination by demonstrating that the previously discussed motives for discrimination are not mutual exclusive. Instead they can be present at the same time and be based on the same piece of information. In our paper, employers only know the employees' origin resulting in wage discrimination motivated by different characteristics of the home provinces. First, we observe in-group favoritism in the form of higher wages for employees with the same origin. Second, discrimination is also based on the ethnical composition in the employees' home province and employers tend to choose lower wages for workers from provinces with larger shares of ethnic minorities. Third, we show that, in addition, wages in our experiments are positively correlated with average wages paid in the home provinces. Furthermore, these different characteristics influence wages independent of each other. Thus, our paper is one of few experimental papers which successfully demonstrate the occurrence of discrimination based on multiple but simultaneously present motives. One notably exception is the work by Falk and Zehnder (2013). In their city wide trust game, first movers condition their trust on the residential districts of second movers in the city of Zürich. The exhibited trust levels differed systematically between the districts of Zürich - higher socio-economic status led to more trust and, for subjects from the same district, in-group favoritism in terms of higher trust was observed. In our experiments, we apply a similar methodology in the context of a stylized employer-employee relationship, however decisions are not conditioned on districts of a city, but on provinces of a whole country.

The remainder of the paper is organized as follows: In Section 2, we discuss the experimental design. This includes the description of the modified gift-exchange game, the implementation of the experiments with students and migrant workers as subjects, and the complementary data on the characteristics of the Chinese provinces. Section 3 presents behavioral hypotheses, Section 4 reports our results on the determinants of employers' wage discrimination and employees' effort provision. Finally, Section 5 discusses the implications of our results and concludes the paper.

\section{Experimental design}

We investigate how employers discriminate employees in two gift-exchange experiments in which wages are conditioned on the employees' home provinces. Using additional field data, we identify particular characteristics of the provinces on which these wages are based on.

The first experiment is a laboratory experiment conducted at the Shanghai Jiao Tong University (PR China) with students deciding in the role of employers and migrant workers in the role of employees. ${ }^{2}$ The second experiment is an internet experiment at the University of Nottingham Ningbo (PR China) with students deciding in both roles - as employers and employees. The second

\footnotetext{
${ }^{1}$ It is worth mentioning that the implications of social identity go beyond discrimination. It applies to most situations in which people behave as they think they should. Thus, social identity provides insights into topics such as the division of labor in households, education, monitoring at the workplace (Akerlof and Kranton, 2000, 2002, 2008), as well as, discounting and risk preferences (Benjamin et al., 2010).

${ }^{2}$ In our paper we refer to workers who migrated to Shanghai from other provinces as migrant workers. In the labor literature on China the term migrant worker usually refers to workers migrating from rural areas to urban areas even if they move within a province.
} 
Table 1

Details on subjects and elicitation methods in the experiments.

\begin{tabular}{lll}
\hline & $\begin{array}{l}\text { Experiment I } \\
\text { Students-migrant workers }\end{array}$ & $\begin{array}{l}\text { Experiment II } \\
\text { Students-students }\end{array}$ \\
\hline Subjects & & 380 Students \\
\# Employer & 98 Students & 380 Students \\
\# Employee & 98 Migrant workers & Ningbo, PR China \\
Location & Shanghai, PR China & \\
Elicitation method & & Strategy method \\
Wage & Strategy method & Strategy method \\
Effort & Direct response & \\
\hline
\end{tabular}

Employers used the strategy method to choose wages conditional on the 27 possible home provinces/regions of the employees. Migrant workers choose their effort with the direct response method given their actual wage. Students in the role of employees used the strategy method choosing their effort conditional on the 10 possible wages.

experiment serves as a robustness check and allows to investigate if the previous results hold if employers face employees with similar socio-economic background. Table 6 in the Appendix gives the origins of all subjects participating in both experiments. In the following, we will first describe our simplified gift-exchange game and the implementation of the experiments. Afterwards, we describe the complementary field data on the characteristics of the employees' origins.

\subsection{The game}

Similar to Fehr et al. (1998), we model the employer-employee relationship as a bilateral gift exchange. In the bilateral giftexchange game one subject decides in the role of an employer and a second subject in the role of an employee. The employer moves first by offering the worker a wage, $11 \leq w \leq 20$. The worker then selects an effort level, $e$, which can either be normal $(e=0)$ or high $(e=1){ }^{3}$ Working hard induces a higher effort cost $(c=10)$, while working normal induces lower effort cost $(c=5)$. The payoffs of the employer were framed such that normal effort increases the employers profit by 5 , while high effort increases the employer's profit by a total of 20. Thus, according to this framing employers' payoff (in RMB) is given as:

$$
\pi_{\text {Employer }}=20+(5+15 e)-w, \quad \text { with } 11 \leq w \leq 20 \text {, and } e \in\{0,1\}
$$

and employees' payoff (in RMB) is given as:

$$
\pi_{\text {Employee }}=w-\left\{\begin{array}{cc}
10 & \text { if working hard, } e=1, \\
5 & \text { if working normal, } e=0 .
\end{array}\right.
$$

To investigate how employers discriminate and base wages on the origin of the employee, wages were set conditional on the origin of the employee. Thus, using the strategy method (Selten, 1967), employers choose for 27 provinces and regions in the PR China wages they would assign to employees from these provinces. ${ }^{4}$ Using the strategy method forces subjects to think about each of the provinces, making the possibility of discrimination very salient and thereby potentially resulting in demand effects (Zizzo, 2010). However, it is unclear whether this decreases or increases the likelihood of discrimination. ${ }^{5}$ Furthermore, even if it increases the likelihood of discrimination it is unlikely to influence the observed discrimination pattern instead of just making it easier to detect. We ultimately decided to use the strategy method as it provides an easy way to obtain sufficiently large numbers of observations.

After wages were set employers and employees were randomly matched. Thereafter, the employee decided to either work hard or normal given the wages, but without any further information on the employer's characteristics.

\subsection{Implementation}

The first experiment was conducted at the Shanghai Jiao Tong University (PR China) and the second one at the University of Nottingham Ningbo (PR China). Both experiments were organized and run by local research assistants, who were not

\footnotetext{
${ }^{3}$ Other studies applying the gift exchange game usually implement the effort as a continuous decisions with convex effort costs (e.g., Fehr et al., 1997, 1998; Brown et al., 2004; Maximiano et al., 2007). We reduce the effort to a binary decision to ensure that the migrant workers understand the game and the consequences of their decisions. As Zhao (2003) reports 91\% of migrant workers in 1999 had no more than nine years of schooling and 17\% no more than six years. Furthermore, we implemented a positive minimum wage to avoid a show-up fee and give all payoffs in the actual currency RMB instead of an experimental currency with a conversion rate.

${ }^{4}$ The list of provinces and regions includes all provinces and autonomous regions. We excluded cities that have the same rank as provinces. The excluded direct-controlled municipalities are Beijing, Chongqing, Shanghai, and Tianjin. Fig. 5 in the Appendix shows a map of the PR China with the used provinces and regions. In this paper we use provinces synonymously for provinces and autonomous regions.

${ }^{5}$ In this context it is worth noting that Experiment I was conducted directly after an employment law became effective which bans discrimination based on ethnic background, race, gender, and religious belief (The Law of the People's Republic of China on Promotion of Employment).
} 

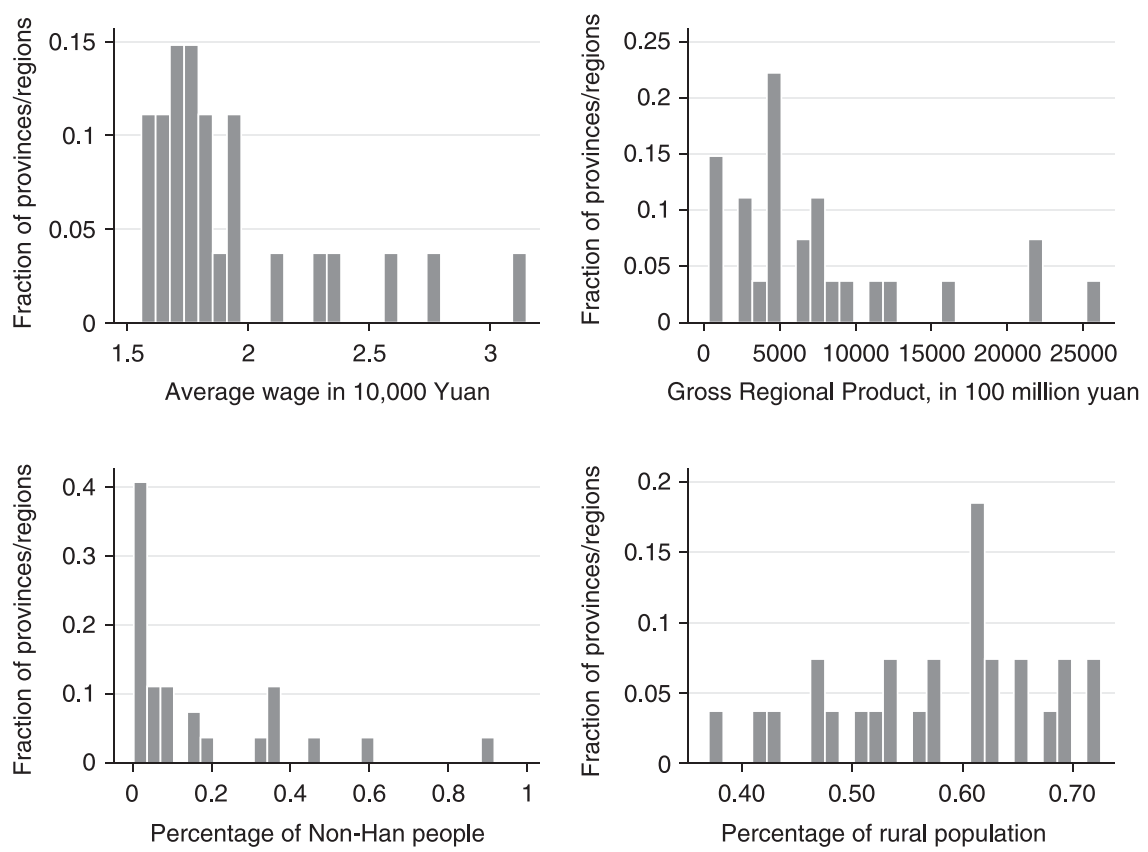

Fig. 1. Different characteristics of provinces/regions.

informed about the research question. Table 1 summarizes the two experiments and gives the number of participating subjects.

In our first experiment students in the role of employers were paired with migrant workers in the role of employees. Students were recruited with postings on bulletin boards and the usual recruiting system of the Vernon-Smith-Lab of the Shanghai Jiao-Tong University. Migrant workers were recruited among construction workers and cleaning staff. ${ }^{6}$ Participating students were scheduled to arrive 10 min prior to the migrant workers' arrival and seated in cubicles. Upon arrival, migrant workers were led into a room next to the laboratory. ${ }^{7}$

In both rooms the instructions were distributed and read aloud. After the assistants had asked control questions the experiment started. In the employer room, students chose the wages based on the worker's origin using the strategy method. In the meantime each migrant worker had to report her/his home province before being anonymously and randomly matched to one employer. Then, the migrant worker was informed about the wage the employer had assigned to her/ him. However, the worker was neither informed about the possibility that employers could assign different wages to provinces, nor the province the employer was coming from. ${ }^{8}$

Thereafter, a questionnaire was distributed. Among demographics, we elicited employers' self-reported general trust towards the people of the 27 provinces/regions. ${ }^{9}$ Meanwhile, final payoffs were calculated and afterwards paid to the participants. The whole experiment was conducted using pen and paper and lasted roughly one hour.

Our second experiment was conducted as an internet experiment at the University of Nottingham Ningbo (PR China). The setup was almost identical to the first experiment. However, this time students decided in the roles of employers and employees. First, all subjects decided in the roles of employers, then they were informed that they would also decide in the roles of employees. Subjects did not receive feedback before completing their decisions as employees. Furthermore, employees' decisions were elicited using the strategy method, i.e., every employee had to choose an effort level for each possible wage.

\subsection{Complimentary field data}

With the data gathered in the experiments we are able to identify wage discrimination, i.e., whether employees from different provinces receive different wages. Yet, to identify potential motives driving this discrimination we complement our

\footnotetext{
${ }^{6}$ See Appendix A for details on recruiting and instructions.

7 The doors of the laboratory were open and students were made aware of the bypassing workers. The purpose of this procedure was to ensure that both students and migrant workers could see each other. Thereby, students were affirmed that they would interact with real migrant workers and the migrant workers were made aware that wages were actually chosen by students.

${ }^{8}$ Again, to keep the setup as simple as possible for the migrant workers they were only asked to choose their effort levels for the actual wage, i.e., no strategy method for the effort decision.

9 We asked employers for each province and region: Do you trust people from this province? The answer was given on a scale from 0 (not trusting at all) to 10 (trusting very much).
} 
experimental findings with additional data on the characteristics of the employees' home provinces. These characteristics were taken from two different datasets.

The 2007 Statistical Yearbook of the Chinese National Bureau of Statistics ${ }^{10}$ provides us with economic characteristics for the provinces, including average annual wages, the percentage of rural population, and the gross regional product in comparison to the gross domestic product. ${ }^{11}$ Average hourly wages were not publicly available, however, in 1995 China adopted a 40-h week for the whole country and thus the annual average wages provide a proxy for the hourly wages. ${ }^{12}$

To capture ethnical differences between provinces we gathered the percentage of the Non-Han population from the 2010 Province Population Census Dataset. ${ }^{13}$ The largest ethnicity is the group of Han Chinese who represent $90 \%$ of the population in China. However, 55 other ethnic groups are officially recognized by the government of the PR China and in most provinces these ethnic groups are minorities. ${ }^{14}$ Instead of distinguishing further between the smaller ethnic groups we focus on the total fraction of people in a province who are not Han Chinese.

Fig. 1 gives histograms for the added variables and demonstrates for most of them a substantial heterogeneity.

\section{Hypotheses}

In the following we derive our hypotheses based on the existing literature. As discussed in the introduction of this paper previous research has identified different motives for discrimination - in this study, we will focus on three of these motives: economic characteristics, in-group affiliations, and ethnic diversity. In Appendix E we present a model which formally incorporates these potential influences. Other forms of discrimination that are based on individuals' characteristics (e.g., age, gender) are not viable in our setting as employers do not have the necessary information.

In our setting employers have to decide on wages with the hope that employers will respond in-kind and exert high effort. According to the fair-wage hypotheses (Akerlof, 1982; Akerlof and Yellen, 1990) an employee will respond kindly to wages above the employee's perceived fair wage and withdraw effort when wages fall short of this benchmark. This fair wage depends on the comparisons with a reference group and, consequently, it will depend on the wages paid at the location of the experiment. In addition, the wage levels of the home provinces might influence the benchmark. ${ }^{15}$ Migrant workers only move to a location if it results in higher income and, thus, every newly offered wage must justify the migration to the new location. If the reference wage were only influenced by the wage level at the location of the experiment it should not lead to differential treatments of employees based on their origin. However, if in addition the evaluation were at least partly influenced by the wages in the employees' home provinces employers would have to take this into account paying more to employees from provinces with higher wages.

Hypothesis 1. Wages in the experiment increase with average wage levels in the provinces.

Our next two hypotheses are aiming at in-group favoritism and out-group discrimination as driving forces for wage discrimination. When employers decide on the wages, they know if they have the same home province as the employee. ${ }^{16}$ Thus, the origins of the employees generate natural in-groups (employees with the same origin as the employer) and out-groups (employees with different origin as the employer). The broad literature on in-group favoritism has demonstrated that subjects tend to treat ingroup members more favorably. Furthermore, Falk and Zehnder (2013) demonstrated that subjects trust strangers from the same city district more than subjects from other districts. Along these lines, we expect employers to exhibit in-group favoritism:

Hypothesis 2. Employers assign higher wages to employees from the same home province.

Another attribute that defines in-groups is the ethnicity of employer and employee. Similar to Fershtman and Gneezy (2001), Fershtman et al. (2005), and Chen et al. (2014) we expect subjects to favor those with the same ethnic background. In our experiments, all employers were Han-Chinese and we expect them to favor employees who are Han-Chinese, too. However, in our experiment employers are not able to observe the ethnicity of an employee. Consequently, we expect a more gradual type of discrimination based on the percentage of Non-Han population in the home province of the employee.

\footnotetext{
${ }^{10}$ We use the 2007 data as it was publicly available when the first experiments were conducted.

11 In addition, we obtained the population size and the number of unemployed. Since both variables were not directly correlated with the wage in the experiment, we do not report them here. For more details refer to the Appendix.

${ }^{12}$ With 52.14 weeks per year this results in hourly wages between 7.48 RMB and $15.11 \mathrm{RMB}$. The average earnings of employees in our experiment are in this region; migrant workers earn on average 7.78 RMB and students $8.81 \mathrm{RMB}$. The range of possible wages was between 11 and $20 \mathrm{RMB}$ resulting in possible earnings for the employees between $1 \mathrm{RMB}$ and $15 \mathrm{RMB}$.

${ }^{13}$ China Data Center, University of Michigan.

14 Only in Tibet and Xinjiang do Han Chinese not account for the majority of the population.

15 On average, migrant workers send 50-55\% of their income as remittances to their families at home (Du et al., 2005). The families at home, i.e., mostly workers' parents and workers' children, have to buy goods and services with these remittances and so the conditions in the provinces are still important when evaluating wages. Another simple reason why wages might be partly evaluated on the basis of the home wages could be inertia. As people move to the new location they might need time to get accustomed to the local wage level.

${ }^{16}$ In China the home province is inherited from the parents and, based on the Hukou system, the only place for which individuals have the legal right to permanently reside. Only in the home province do individuals enjoy citizens' rights such as welfare benefits and school access for their kids. The home province is rather fixed and very hard to change.
} 


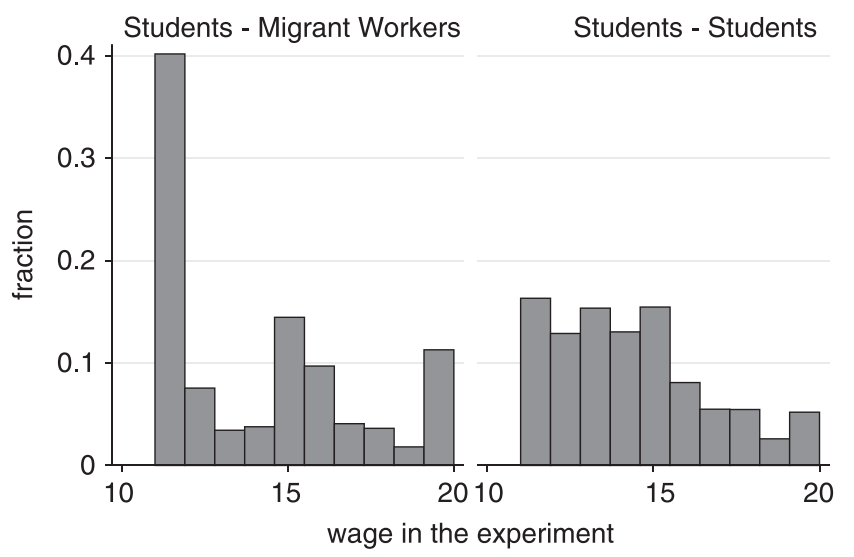

Fig. 2. Distribution of wages in the two experiments.

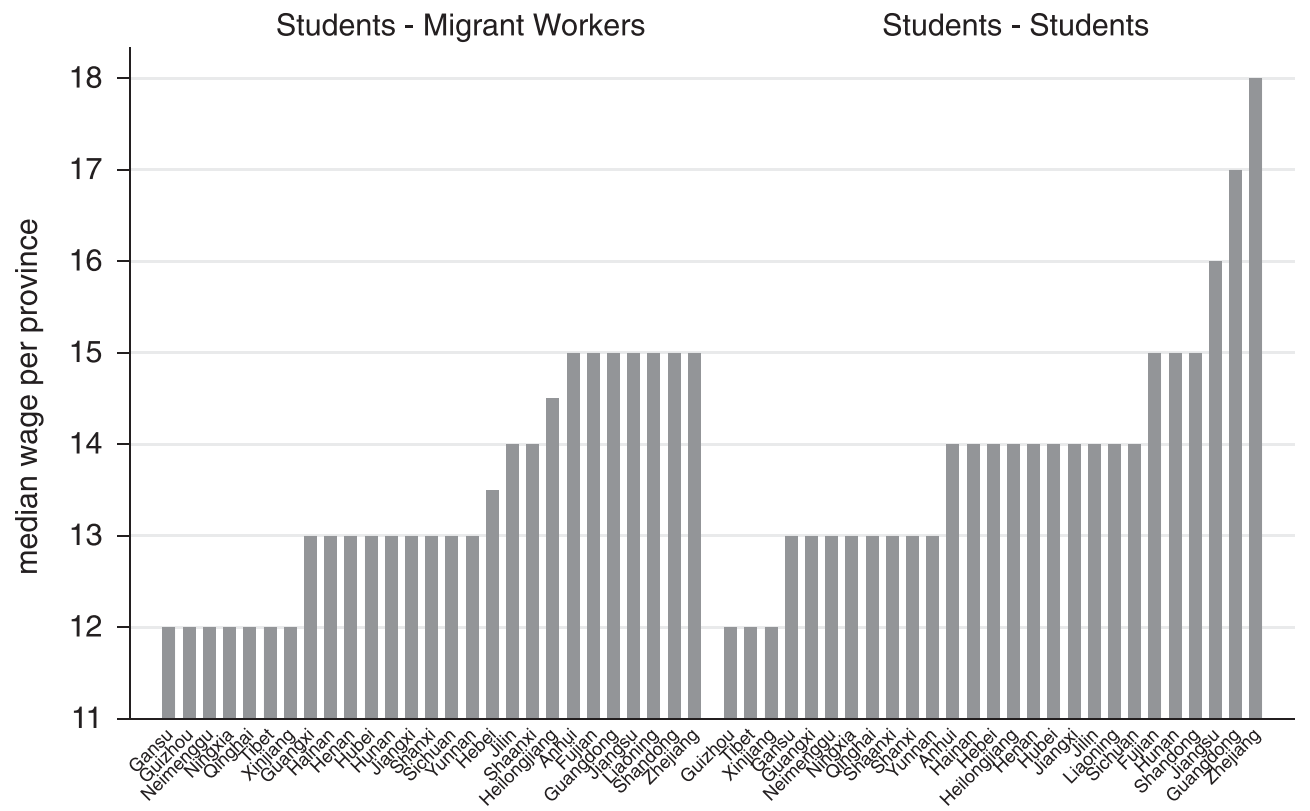

Fig. 3. Median wages per province, ordered by median wages.

An increasing percentage of the Non-Han population raises the probability of being paired with an employee with a different ethnicity, i.e., an out-group member. ${ }^{17}$

Hypothesis 3. Assigned wages decline with increasing shares of Non-Han Chinese in the employees' home province.

In the following we discuss the expected behavior of the employees. Employees in our experiment did not receive information on the origin of the employer. Therefore, in-group favoritism is an unlikely influence on the effort decision. Nevertheless, we have two predictions based on the fair wage hypotheses. The first one is in line with the general findings in the laboratory gift-exchange literature demonstrating a positive effort response to increasing wages (for recent reviews, see Charness and Kuhn, 2011; Cooper and Kagel, 2016).

Hypothesis 4. Increasing wages lead to increasing effort regardless of the origin of the employees.

And finally, given a fixed wage we would expect different effort levels among provinces if the reasoning behind hypotheses 1 is correct and employees evaluate the appropriateness of wages based on the average wages paid in their home province.

Hypothesis 5. Given the same wage in the experiment employees from provinces with higher average wages should exert less effort.

\footnotetext{
${ }^{17}$ Similar to this argument is the observation by Grimm and Mengel (2009) that in viscous populations with endogenous groups individuals are more likely to interact with similar types/individuals. In the investigated prisoner's dilemma, this selection ultimately increases cooperation.
} 
Table 2

Explaining the wage in the experiment.

\begin{tabular}{|c|c|c|c|c|c|c|}
\hline \multirow[t]{2}{*}{ Wage in experiment } & \multicolumn{3}{|c|}{ Students-migrant workers } & \multicolumn{3}{|c|}{ Students-students } \\
\hline & (1) & (2) & (3) & (4) & (5) & (6) \\
\hline Average Wage Origin & 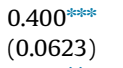 & $\begin{array}{l}0.338^{* * * * *} \\
(0.0715)\end{array}$ & $\begin{array}{l}0.175^{* * *} \\
(0.0718)\end{array}$ & 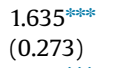 & $\begin{array}{l}1.244^{* * * * *} \\
(0.243)\end{array}$ & $\begin{array}{l}0.665^{\text {***** }} \\
(0.192)\end{array}$ \\
\hline Same Origin & $\begin{array}{l}0.502^{* * *} \\
(0.211)\end{array}$ & $\begin{array}{l}0.437^{* * *} \\
(0.212)\end{array}$ & $\begin{array}{l}0.382^{*} \\
(0.211)\end{array}$ & $\begin{array}{l}1.373^{\text {**** }} \\
(0.193)\end{array}$ & $\begin{array}{l}1.223^{* * k * *} \\
(0.161)\end{array}$ & $\begin{array}{l}1.266^{* * * * *} \\
(0.146)\end{array}$ \\
\hline \% NonHan Origin & 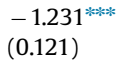 & $\begin{array}{l}-1.050^{* * * *} \\
(0.168)\end{array}$ & $\begin{array}{l}-0.641^{\text {***kl }} \\
(0.187)\end{array}$ & $\begin{array}{l}-3.749^{\text {*k*** }} \\
(0.497)\end{array}$ & $\begin{array}{l}-2.784^{* * * *} \\
(0.509)\end{array}$ & $\begin{array}{l}-1.416^{* * * *} \\
(0.381)\end{array}$ \\
\hline \% Rural Origin & & $\begin{array}{l}-0.498 \\
(0.353)\end{array}$ & $\begin{array}{l}0.0419 \\
(0.433)\end{array}$ & & $\begin{array}{l}-3.306^{* * * *} \\
(1.033)\end{array}$ & $\begin{array}{l}-3.383^{* k * k} \\
(1.110)\end{array}$ \\
\hline Trust in Origin & & $\begin{array}{l}0.0493^{* * *} \\
(0.0206)\end{array}$ & $\begin{array}{l}0.0476^{\text {**k }} \\
(0.0202)\end{array}$ & & 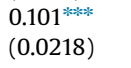 & 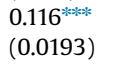 \\
\hline Constant & $\begin{array}{l}13.40^{* * * * *} \\
(0.114)\end{array}$ & $\begin{array}{l}13.49^{* * * *} \\
(0.323)\end{array}$ & $\begin{array}{l}13.52^{\text {**k*k }} \\
(0.351)\end{array}$ & $\begin{array}{l}11.65^{* * * * *} \\
(0.492)\end{array}$ & 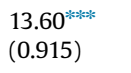 & $\begin{array}{l}14.62^{\text {*kek }} \\
(0.791)\end{array}$ \\
\hline Additional Controls & No & No & Yes & No & No & Yes \\
\hline Employer FE & Yes & Yes & Yes & Yes & Yes & Yes \\
\hline Observations & 2646 & 2646 & 2646 & 10,260 & 10,260 & 10,260 \\
\hline Subjects & 98 & 98 & 98 & 380 & 380 & 380 \\
\hline Prob $>F$ & $p<0.001$ & $p<0.001$ & $p<0.001$ & $p<0.0001$ & $p<0.0001$ & $p<0.001$ \\
\hline
\end{tabular}

Table reports regressions of wage decisions by employers on employees' province characteristics. All columns give panel regressions with employer fixed effects and robust clusters on the level of the province the wage was assigned to. Additional covariates are the gross regional product relative to the gross domestic product and region dummies (Central China, East China, South China, Western China, North China, and Northeast China). Table 8 in the Appendix reports all coefficients.

***** $p<0.01$.

$* * * 0.05$.

$* p<0.1$.

\section{Results}

\subsection{Employers' behavior}

Fig. 2 gives the distribution of wages in the two experiments. Mean wages between the two experiments differ only slightly, with migrant workers receiving lower wages as employees (13.98) compared to students ( $14.24, p=0.23$ two-sided Fisher-Pitman permutation test for independent samples, FPI). ${ }^{18}$ However, the figure reveals that the two distributions look quite differently $\left(p<0.001\right.$, Epps-Singleton Empirical Characteristic Function test). ${ }^{19}$ Migrant workers in the role of employees receive significantly more often the lowest possible wage of 11 ( $p<0.001$, FPI), but also significantly more often the maximum wage of 20 ( $p<0.01$, FPI).

We now turn our attention to the question whether different wages are assigned to employees from different provinces. Fig. 3 gives the mean wages per province assigned to migrant workers in Experiment I (left) and students in Experiment II (right). The wages are ranked from the lowest to the highest and while the order in both experiments is not exactly the same, assigned mean wages for the provinces are highly correlated between the two experiments $(r=0.8708$ with $p<0.001$ ). The figure clearly demonstrates heterogeneity in the assigned wages and 140/301 out of the 338 possible pairwise comparisons of wages between two provinces are significant in our experiment with migrant workers/students as employees (all $p<0.05$, two-sided Fisher-Pitman permutation test for paired replicates, FPP). ${ }^{20}$ Although the figure reveals that on average different wages are assigned to the provinces some employers are insensitive to the employees' origin. In fact, $44 \%$ of the employers matched with migrant workers assign the same wage to all employees regardless of their origin, while only $3 \%$ do so when matched with students. However, 55\% of those who do not discriminate in Experiment I assign the lowest wage to all migrant workers and 33\% do so in Experiment II. Fig. 5 in the Appendix presents the distribution of wages assigned by employers who do not discriminate.

We now test whether certain province characteristics explain the ranking of wages given in Fig. 3. We first investigate each hypothesis separately with non-parametric tests. Thereafter, we run a series of regression analyses to confirm that the described results are indeed due to separate effects which remain significant when controlling for them simultaneously.

\footnotetext{
18 The Fisher-Pitman permutation tests are more powerful alternatives to the Wilcoxon signed-rank test and the Wilcoxon-Mann-Whitney rank-sum test. For more details refer to Kaiser (2009).

19 The Epps-Singleton Empirical Characteristic Function test is an alternative to the Kolmogorov-Smirnov test and usually has a greater power. In contrast to the Kolmogorov-Smirnov test it can be applied to discrete data. For more details refer to Goerg and Kaiser (2009).

${ }^{20}$ Obviously, these comparisons are problematic with regard to multiple testing. However, after applying the very conservative Bonferroni correction 21 (students-migrant worker) and 261 (students-students) pairwise comparison remain significant on the 5\% level in both experiments.
} 


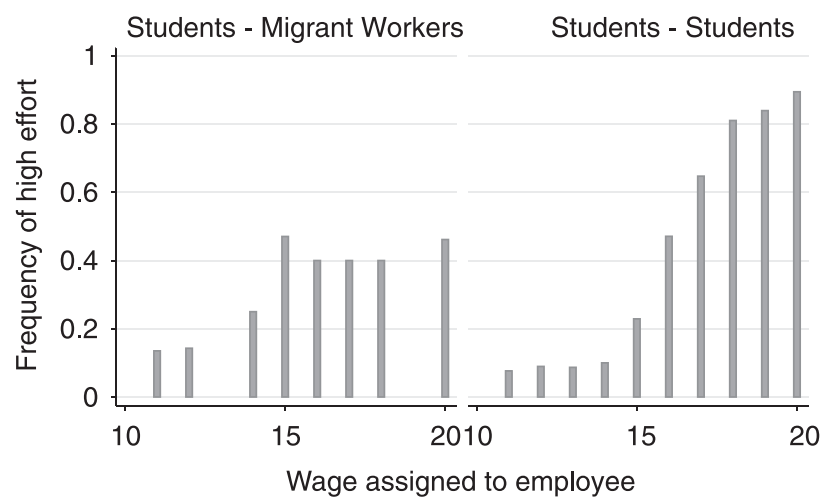

Fig. 4. Average effort per wage in the two experiments.

The provinces with the highest wage levels in the field tend to receive the highest wages in our experiment. The provinces in which the second, third and fourth highest wages are paid in the real economy (Zhejiang 27,820 RMB; Guangdong 26,186 RMB; Jiangsu 23,782 RMB) are in both experiments among the provinces that receive the highest median wages ( $\geq 15 \mathrm{RMB}$ ). In both experiments, employers assign significantly lower wages to workers from provinces with real life wages below the median - no matter whether these workers were migrant workers $(p=0.055$, FPP $)$ or students $(p<0.001)$.

Result 1. Employees assign higher wages to provinces with higher average wages in the field. This occurs in both experiments.

In Experiment I, the largest number of employers is originally from the province Jiangsu. In Experiment II, most employers originated from Zhejiang. ${ }^{21}$ In both of the experiments these two provinces are among the ones with the highest assigned median wages. Comparing the wages employers assigned to employees from their home provinces with the mean wages assigned to the other provinces clearly reveals signs of in-group favoritism with higher mean wages for the home province. When matched with migrant workers from the home provinces wages are on average 6\% higher than for the other provinces $(p<0.001, \mathrm{FPP})$. This effect is even more pronounced when employers are matched with students as the home provinces of the employers receive on average $19 \%$ higher wages $(p<0.001$, FPP).

Result 2. Employers exhibit signs of in-group bias by assigning higher wages to their home provinces.

Given the relationship between actual wages and wages in the experiment, Tibet is clearly an exception. According to the field data on provinces, workers in Tibet receive the highest average wages (31,518 RMB), but in both of our experiments assigned median wages were very low (12 RMB). However, Tibet is among the three provinces with the highest percentages of Non-Han Chinese (Tibet 92\%; Xinjiang 60\%; Qinghai 47\%) and all three provinces received the lowest median wage (12 RMB). Overall, in both experiments employers assigned significantly lower wages to provinces with above median populations of minorities (both experiments $p<0.001$, FPP).

Result 3. Employees assign lower wages to provinces with higher shares of minorities.

Our previously presented results could be due to the fact that province characteristics are correlated with each other. Table 7 in the Appendix presents these correlations. To control simultaneously for all three discussed motive for discrimination we conduct a series of regressions with employer fixed-effects and robust standard errors clustered at the province level. Models 1-3 in Table 2 give the estimates for Experiment I and Models 4-6 for Experiment II.

In Models 1 and 4 the coefficients for Average Wage Origin, Same Origin, and \% NonHan Origin are all significant at the same time confirming that they are indeed distinct motives for discrimination. We observe the same pattern in both Experiments, but the absolute size of the coefficients for employers matched with students is significantly larger compared to the ones for employers matched with migrant workers. Table 9 in the Appendix demonstrates that the differences in magnitudes between the two experiments are statistically significant.

The reported results on discrimination in Table 2 are on the aggregate level, but a closer look at the individual level reveals that roughly $93 \%$ of the discriminating employers base their decision on at least one of the three motives with substantial fractions of employers being influenced by several motives at the same time. ${ }^{22}$ In Experiment I, $29 \%$ of employers discriminate based on Average Wage Origin, Same Origin, and \% NonHan Origin at the same time, while $35 \%$ discriminate based on two of the three motives. In Experiment II, 23\% of employers are influenced by three motives and $49 \%$ on two motives at the same time.

\footnotetext{
${ }^{21}$ In Experiment I employers from Henan have the highest probability to be matched with an employee from the same province (45\%), in Experiment II it is employers from Zhejiang (63\%). The average probability of being matched with an employer from the same province is $5.6 \%$ in Experiment I and $41 \%$ in Experiment II. See Table 6 in the Appendix for the origins of the subjects.

22 To classify the discrimination, we individually regress for each employer $w_{p}=y_{0}+y_{1} c_{1 p}+y_{2} c_{2 p}+y_{3} c_{3 p}+\epsilon_{p}$, with $w_{p}$ being the assigned wage to a province and $c_{1 p}, c_{2 p}$ and $c_{3 p}$ being the motives Average Wage Origin, Same Origin, and \% NonHan Origin. If an estimated coefficient is significant on the 10\% level we classify this employer as someone who discriminates based on this motive. Table 10 in the Appendix reports the results of this classification approach.
} 
Table 3

Explaining high effort.

\begin{tabular}{|c|c|c|c|c|}
\hline \multirow[t]{2}{*}{ Prob(High Effort) } & \multicolumn{2}{|c|}{ Students-migrant workers } & \multicolumn{2}{|c|}{ Students-students } \\
\hline & (1) & (2) & (3) & $(4)$ \\
\hline Wage in experiment & & $\begin{array}{l}0.2444^{* * * *} \\
(0.080)\end{array}$ & & 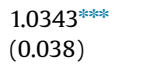 \\
\hline Worker's Origin Real Wage & $\begin{array}{l}1.0678 \\
(1.652)\end{array}$ & $\begin{array}{l}1.2493 \\
(1.738)\end{array}$ & $\begin{array}{l}-0.0565 \\
(0.163)\end{array}$ & $\begin{array}{l}-0.1559 \\
(0.413)\end{array}$ \\
\hline Worker's Origin \% NonHan & $\begin{array}{l}-4.4436 \\
(6.660)\end{array}$ & $\begin{array}{l}-5.3597 \\
(8.688)\end{array}$ & $\begin{array}{l}1.1770 \\
(0.822)\end{array}$ & $\begin{array}{l}2.9427 \\
(2.082)\end{array}$ \\
\hline Worker's Origin \% rural & $\begin{array}{l}3.8897 \\
(7.110)\end{array}$ & $\begin{array}{l}6.2452 \\
(7.632)\end{array}$ & $\begin{array}{l}-1.5996 \\
(1.021)\end{array}$ & $\begin{array}{l}-4.0650 \\
(2.582)\end{array}$ \\
\hline Worker Female & $\begin{array}{l}-0.5333 \\
(0.630)\end{array}$ & $\begin{array}{l}-0.7870 \\
(0.685)\end{array}$ & $\begin{array}{l}-0.1028 \\
(0.114)\end{array}$ & $\begin{array}{l}-0.2532 \\
(0.289)\end{array}$ \\
\hline Worker's Age & $\begin{array}{l}0.0305 \\
(0.022)\end{array}$ & $\begin{array}{l}0.0437^{*} \\
(0.024)\end{array}$ & $\begin{array}{l}0.0014 \\
(0.005)\end{array}$ & $\begin{array}{l}0.0038 \\
(0.014)\end{array}$ \\
\hline Constant & $\begin{array}{l}-5.9813 \\
(7.437)\end{array}$ & $\begin{array}{l}-11.6432 \\
(8.140)\end{array}$ & $\begin{array}{l}0.5791 \\
(0.835)\end{array}$ & $\begin{array}{l}-14.5151^{\text {*k*k* }} \\
(2.178)\end{array}$ \\
\hline Observations & 98 & 98 & 3800 & 3800 \\
\hline Subjects & 98 & 98 & 380 & 380 \\
\hline Prob $>\chi^{2}$ & 0.510 & 0.0228 & 0.432 & $p<0.001$ \\
\hline
\end{tabular}

Table reports logit regressions explaining the probability of high effort. Estimates for Experiment II are based on random-effects logistic regression.

** $p<0.05$

$* * * * 0<0.01$

$* p<0.1$.

In Models 2 and 5, we control for the ruralness of the employees' origin as rural-to-urban migration is associated with a social stigma and discrimination (Wang et al., 2010). The large rural-urban divide in China results in discrimination towards rural migrants (Meng and Zhang, 2001) as the hukou system reduces urban job opportunities, thereby lowering the bargaining power and ultimately pushing the wages below the workers marginal products (Dollar and Jones, 2013). Thus, our previously reported results could be indications for discrimination based on the rural background of the employees and we control for this possible confound. In line with the previous literature, we observe lower wages for employees from more rural provinces in Experiment II. ${ }^{23}$ Yet, the influence of ruralness is a separate effect from Average Wage Origin, Same Origin, and \% NonHan Origin; their coefficients remain significant in both experiments.

In addition, we control in Models 2 and 5 for the trust towards the provinces. In both experiments, employers' selfreported trust towards people with the same home province is more than $25 \%$ higher compared to those from other provinces. ${ }^{24}$ Yet, the positive impact of trust on wages exceeds a mere in-group favoritism effect as the coefficients for both Trust in Origin and Same Origin in Table 2 remain positive and significant.

After adding further controls for gross regional product and regions in Models 3 and 6, results remain qualitatively the same. In the Appendix we report additional robustness checks and demonstrate that our results are not influenced by the mere ranking of wage levels, the number of unemployed, the population size, or the fact that not all decisions of the strategy method are equally likely to be payoff relevant. Thus, we can confirm hypotheses 1,2 , and 3 .

Result 4. In Experiment II lower wages are assigned to provinces with larger fractions of rural population. In both of our experiments employers tend to assign higher wages to employees from provinces they perceive as more trustworthy. All previously reported results remain robust to additional controls.

\subsection{Employees' behavior}

We now turn to the behavior of the second movers and analyze whether the variables on which wages are conditioned actually influence the effort decisions of the employees. Fig. 4 gives the average effort decision for each possible wage. Recall that the effort decisions in Experiment I were based on the actual wage levels, while in Experiment II they were elicited with the strategy method. Thus, the number of effort responses per wage varies a lot in the graph on the left, but are constantly 380 in the graph on the right. ${ }^{25}$

\footnotetext{
${ }^{23}$ One potential reason why ruralness does not significantly influence assigned wages in Experiment I could be the origin of migrant workers in Shanghai. The Shanghai Municipal Bureau of Statistics reported in 2011 that $79.4 \%$ of the interprovincial migrants were coming from rural occupations. Thus, employers in Experiment I might have considered all employees as rural resulting in no variation along this variable. This would also explain the large fraction of employees receiving the lowest possible wage.

24 Based on fixed effects regressions explaining trust with a dummy for the same province. The coefficient is in both experiments highly significant.

25 The strategy method allows a cleaner analysis of employees' decisions as we observe counterfactuals for every possible wage. One could argue that in our first experiment potential influences on the effort are already taken into account by the wage setting employer and thus we would not be able to
} 
In line with the previous gift-exchange literature we observe a significantly positive increase of effort with increasing wages in both experiments (Experiment I: $r=0.20$ with $p<0.01$, Experiment II: $r=0.65$ with $p<0.001$ ). ${ }^{26}$ In the following we investigate if there are additional influences on the employees' effort decision beyond the wage paid by the employee. Specifically, we want to see whether those characteristics influencing the employers' decisions are predictive for employees' effort.

In both experiments employees come from provinces with varying average wages (in both experiments the lowest average wage in the home province of an employee was 15,590 RMB and the highest was 27,820 RMB). On average, migrant workers originated from provinces with significantly lower wages (19,632 RMB) than student employees (24,281 RMB, $p<0.001$, FPP). However, while the employers' wage decisions are influenced by the average wages in the home provinces we do not observe any signs for such an influence on employees' effort decisions (Experiment I: $r=0.4, p=0.45$; Experiment II: $r=0.08, p=0.37$ ).

Another variable that influences employers' wage decision is the ethnical heterogeneity of the home provinces. And in both experiments employees are coming from provinces with diverse ethnical backgrounds, the lowest percentages of NonHan Chinese in home provinces are below $1 \%$ and the highest are 59\%. Yet, no significant correlation exists between the percentage of Non-Han Chinese and exerted effort, neither in Experiment I $(r=-3.6, p=0.34)$ nor in Experiment II $(r=0.35$, $p=0.59$ ). In addition, home provinces differ substantially with regard to the percentage of rural population, the lowest percentage is $37 \%$ and highest $72.5 \%$. While the ruralness of a province influenced the assigned wage it does not influence the effort (Experiment I: $r=-0.96, p=0.68$; Experiment II: $r=-0.77, p=0.17$ ).

Potentially, average wages, as well as, ethnical and rural composition in the home provinces influence the effort only conditional on the assigned wage. Therefore, we conduct as a last step of our analyses a series of logit regressions with additional controls. Table 3 gives the estimates. Again no significant influences of province characteristics are observed only assigned wages in the experiment increase the employees' effort. ${ }^{27}$

While the positive relationship between assigned wage and effort was expected and is in line with our hypothesis, the missing connection between average wage levels in the home province and effort in the experiment is not in line with our hypothesis. Thus, we can confirm hypothesis 4 , but have to reject hypothesis 5 .

Result 5. The characteristics that influence employers' wage decisions do not predict effort. Only the wage assigned in the experiment influences the effort decision.

\section{Conclusion}

In this paper we demonstrated that an employees' origin can simultaneously trigger different motives for wage discrimination. In our bilateral gift-exchange experiments employers conditioned wages on employees' home provinces. Combining our experimental data with additional field data on the characteristics of Chinese provinces we were able to demonstrate that employers' discrimination was correlated with the actual wage level in the provinces, the ethnic composition in these provinces and whether the employee originated from the same home province. In addition, we observe that wages decrease with increasing ruralness of provinces. However, these variables do not significantly influence the employees' effort levels, only increasing assigned wages lead to higher effort.

The fact that the actual wage level in the employees' home provinces influenced the wage in our experiment is in line with the fair-wage hypothesis (Akerlof and Yellen, 1990). In addition, group-identity and in-group favoritism within natural groups can explain the preferential treatment of employees with the same origin, as well as, lower wages to employees from provinces with higher ethnic heterogeneity. Overall, our results are remarkably robust as they are based on data collected in two different locations and hold for employers with higher socio-economic status than the employees (i.e., student employers being matched with migrant workers) as well as for employers with similar socio-economic background as the employees (i.e., student employers being matched with student employees).

We investigated the different motives for wage discrimination in an artefactual setting. Given the extensive debate on the external validity of laboratory studies (e.g., Gneezy and List, 2006; Levitt and List, 2007; Cohn et al., 2014; Camerer, 2015; Herbst and Mas, 2015) the next step should be to replicate our results in a natural environment. If our results replicate in the field, they would be relevant for the discussion of anonymous job application procedures in which information on an applicant's race or gender is removed from the resume to reduce discrimination in the hiring process (Hausman, 2012). Previous findings demonstrate that anonymous applications have the potential to reduce discrimination (Åslund and Skans, 2012), but also potentially unindented effects (Krause et al., 2012; Behaghel et al., forthcoming). Our results suggest, that already as little as an employee's origin might provide distinct motives for discrimination.

\footnotetext{
(footnote continued)

identify these influences on the effort. The strategy method in the second experiment circumvents this potential criticism. Nevertheless, for completeness, we report the results of our analysis for both experiments.

${ }^{26}$ Logistic regression with clusters on the employee level in Experiment II.

27 In addition, we checked for Experiment II whether the wage decision made in the role of an employer influenced the effort decision in the role of an employee. Neither the assigned wage to the home province, nor whether the subject choose discriminating wages influenced the effort decision significantly. Controlling for both does not change the reported non-results (see Table 15 in the Appendix).
} 


\section{Acknowledgments}

For helpful comments, we would like to thank Javier Cano-Urbina, David Cooper, Christoph Engel, Armin Falk, Bruno Frey, Carl Kitchens, Sebastian Kube, two anonymous referees, the editors, as well as, participants at various meetings and seminars at Florida State University, Luxembourg, Sichuan University, University of Bonn, University of Michigan, and University of Zürich.

\section{Appendix A. Experimental procedures}

\section{A.1. Recruitment of Subjects in Shanghai}

Recruitment of student participants: At the Vernon-Smith-Lab of the Shanghai Jiao-Tong University (SJTU) all the subjects were recruited through black boards. The announcement invited students to participate at a decision making experiment, in which they could earn money, depending on their decision and the decisions of others. No further information, besides the date, time, place and duration was given. The invitation text at the board was in Chinese and there was no connection to an institution (university, research agency) outside SJTU. To sing-up, students had to send an email to the person responsible for the recruitment at SJTU. The students could sign-up to participate in the experiment at the laboratory of the Xuhui Campus or Minhang Campus of SJTU. Thus students had the opportunity to pick a location that was the closest to their dorm or classes.

Recruitment of the migrant workers: Eight student helpers (all Chinese) visited construction sites and cleaning agencies in Shanghai to talk to the gangers of migrant workers. The assistants explained that we will do a decision-making experiment and that we were looking for randomly recruited migrant workers. Details for the experiment were not revealed in the explanation. However, the gangers were told that the participating workers would earn some money based on their decisions and the decisions of other participants. Furthermore, the helpers asked for a heterogenous set of workers, coming from different regions of the PR China, and without a permanent permission to stay in Shanghai. After the gangers understood the purpose of our request they talked to the management of the construction sites for their permission and arrange that workers could participate during their rest periods. Depending on the location of the construction site workers were either sent to the laboratory of Xuhui Campus or Minhang Campus of SJTU.

\section{A.2. Recruitment of subjects in Ningbo}

Students were invited to participate in an online experiment via email. When students signed-up they received an 10 digit unique identification number which they could later use to receive their payments from the experiment. When subjects registered for the experiments they were asked for their home provinces. If a subject was from one of the excluded municipalities (Beijing, Chongqing, Shanghai, and Tianjin) she was told that she could unfortunately not participate in the experiment. To participate students needed a computer with an internet connection to open the website of the experiment. The details of the experiment were explained on the screen and the instructions were based on the ones from Shanghai adjusted for the internet environment and for the pure student sample. After the experimental sessions, subjects came to the assistant's office and received their payments based on their unique identification number.

\section{A.3. Instructions (translated into English)}

Welcome everyone, you are about to participate in an economic experiment. This experiment will last for about forty minutes. If you read the Instructions carefully and make good decisions, you may earn a considerable amount of money. It is very important that you do not talk to other participants for the time of the entire experiment.

In the experiment, each student will be randomly matched with a migrant worker and the pair forms an employment relationship. Students are the employers and workers the employees. Each student is endowed with $20 \mathrm{RMB}$ as an initial endowment. From this endowment, the students decide how much to pay the matched migrant worker as a wage. Students can condition their wage on the origin of the migrant workers (the wage should be an integer no less than 11 RMB and no more than $20 \mathrm{RMB}$ ). After receiving the wage, each worker decides to work hard or to work normal for the matched student. It costs the worker $10 \mathrm{RMB}$ to work hard but generates a profit of $20 \mathrm{RMB}$ for the student, while it costs the worker $5 \mathrm{RMB}$ to work normal generating a profit of 5 RMB for the student.

Earnings student $=20$ RMB - wage paid to worker + profit from worker's work

Earnings worker $=$ wage received - cost of work

Example: If the student decides to give the worker $15 \mathrm{RMB}$ as a wage, and the worker decides to work hard, the earnings are:

Earnings student $=20 \mathrm{RMB}-15 \mathrm{RMB}+20 \mathrm{RMB}=25 \mathrm{RMB}$

Earnings worker $=15 \mathrm{RMB}-10 \mathrm{RMB}=5 \mathrm{RMB}$ 
1. Now that every participant has the instructions and a decision sheet, please put your code number on the upper-right side of your decision sheet.

2. Please state in your decision sheet the wages you would like to offer to workers from different provinces (the wage should be an integer no less than $11 \mathrm{RMB}$ and no more than $20 \mathrm{RMB}$ ). After that, please predict the effort for workers from each province given the wage you offered.

3. After all decisions have been done our lab assistants will calculate the earnings of each participant and pay you in cash. In the meantime please fill-out the distributed questionnaire.

Please raise your hand if you have any further questions.

Sequence of the Experiment: (Migrant Workers)

1. Now that every participant has the instructions and a decision sheet, please put your code number on the upper-right side of your decision sheet.

2. Please state your origin in the first line of the decision sheet, and your expected wage from the matched student in the second line.

3. On your decision sheet our lab assistants will write down the wage you received from the matched student. Please decide if you would like to work normal or work hard for the student.

4. After all decisions have been done our lab assistants will calculate the earnings of each participant and pay in cash. In the meantime please fill-out the distributed questionnaire.

Please raise your hand if you have any further questions.

Table 4

Decision sheet employer.

\begin{tabular}{|c|c|c|c|}
\hline Province & Wage to employee $11 \leq$ Wage $\leq 20$ & You believe employee will work & Your match (by assistants) \\
\hline Sichuan & & Normal / Hard & \\
\hline Guizhou & $\longrightarrow$ & Normal / Hard & \\
\hline Guangdong & & Normal / Hard & \\
\hline Zhejiang & & Normal / Hard & \\
\hline Fujian & 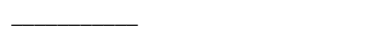 & Normal / Hard & \\
\hline Hunan & & Normal / Hard & \\
\hline Hubei & & Normal / Hard & \\
\hline Shandong & & Normal / Hard & \\
\hline Shanxi & 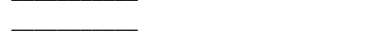 & Normal / Hard & \\
\hline Henan & & Normal / Hard & \\
\hline Hebei & & Normal / Hard & \\
\hline Jilin & & Normal / Hard & \\
\hline Liaoning & & Normal / Hard & \\
\hline Heilongjiang & & Normal / Hard & \\
\hline Anhui & & Normal / Hard & \\
\hline Jiangsu & & Normal / Hard & \\
\hline Jiangxi & & Normal / Hard & \\
\hline Hainan & & Normal / Hard & \\
\hline Shaanxi & & Normal / Hard & \\
\hline Yunnan & & Normal / Hard & \\
\hline Qinghai & & Normal / Hard & \\
\hline Ningxia & $\longrightarrow$ & Normal / Hard & \\
\hline Gansu & & Normal / Hard & \\
\hline Xinjiang & & Normal / Hard & \\
\hline Tibet & & Normal / Hard & \\
\hline Guangxi & $\longrightarrow$ & Normal / Hard & \\
\hline Neimenggu & $\bar{L}$ & Normal / Hard & \\
\hline \multirow{2}{*}{\multicolumn{2}{|c|}{$\begin{array}{l}\text { Your matched employee decides to work: } \\
\text { Your earning is: }\end{array}$}} & Normal / Hard & (by assistants) \\
\hline & & RMB & (by assistants) \\
\hline
\end{tabular}

Table 5

Decision sheet migrant worker.

\begin{tabular}{|c|c|c|}
\hline & & Code: \\
\hline You are from & & Province \\
\hline Your expected wage & RMB & $(11 \leq$ Wage $\leq 20)$ \\
\hline The matched student decides to pay you & RMB & (by assistants) \\
\hline You decide to work & Normal/hard & \\
\hline Your total earnings & RMB & (by assistants) \\
\hline
\end{tabular}




\section{Appendix B. Figures}

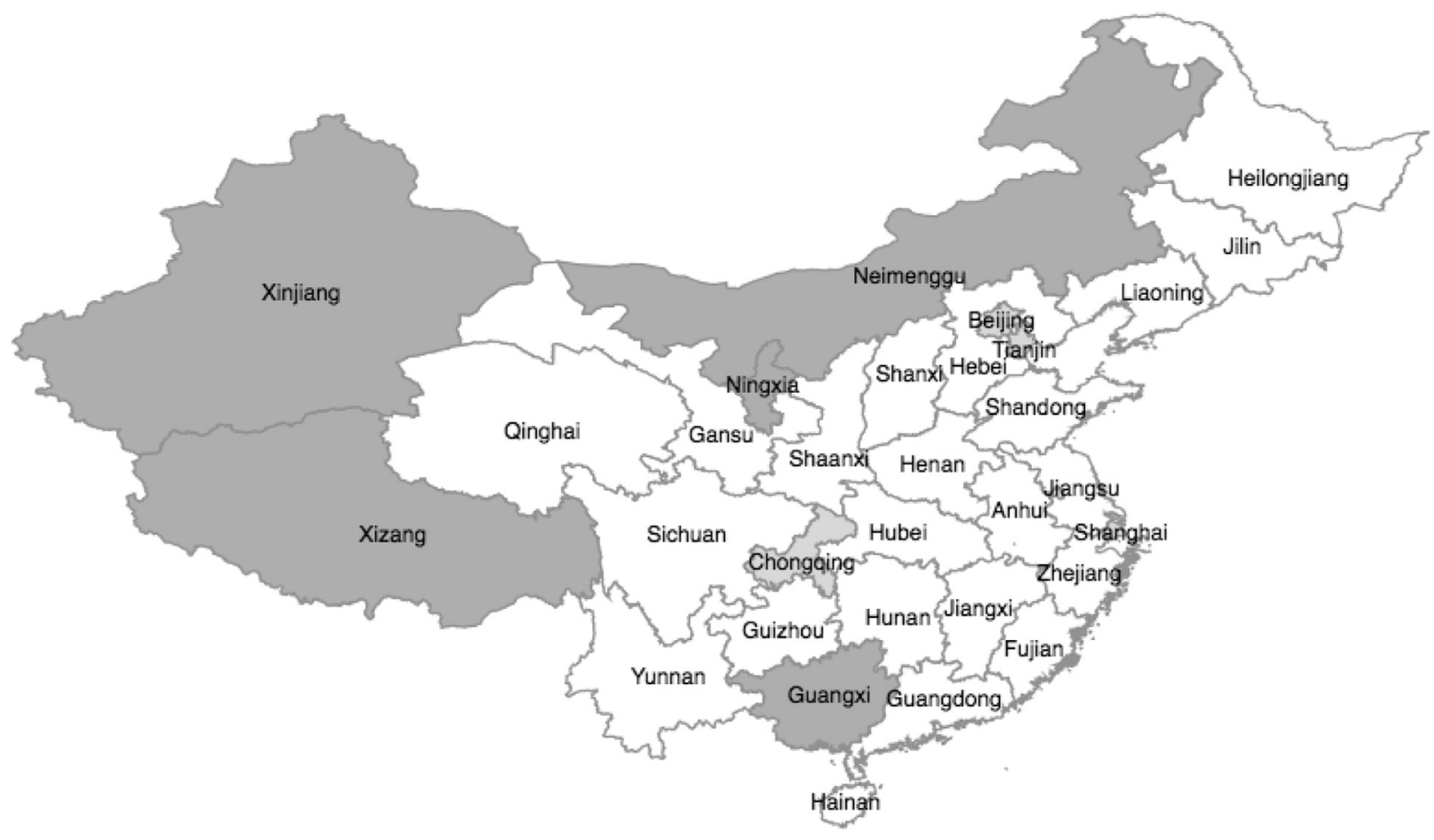

Autonomous regions

Fig. 5. China and its provinces.

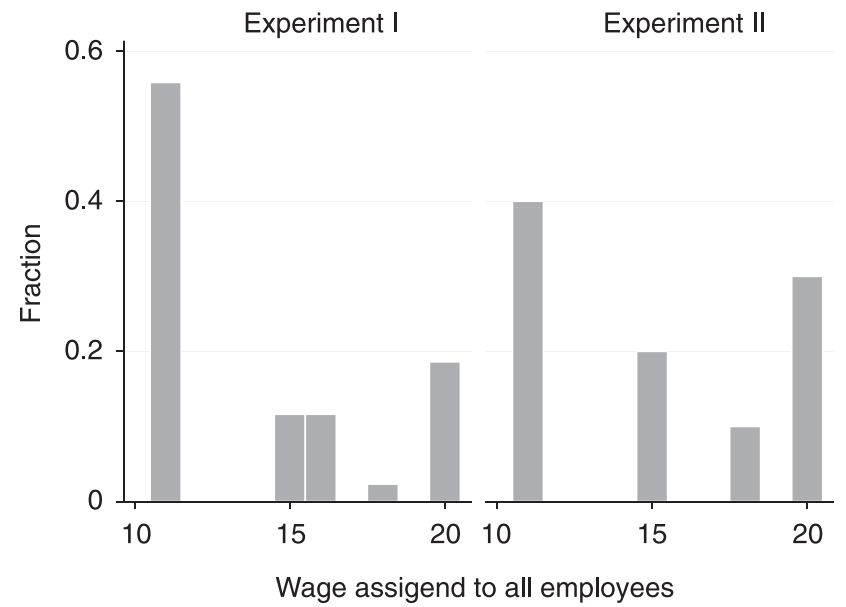

Fig. 6. Assigned wages by employers who do not discriminate. Note: Roughly $43.9 \%$ of employers in Experiment I choose the same wages for all subjects, $2.4 \%$ did so in Experiment II. 


\section{Appendix C. Tables}

See Tables 6-10.

Table 6

Origin subject pool-percentages per province.

\begin{tabular}{|c|c|c|c|c|c|}
\hline \multirow{3}{*}{$\begin{array}{l}\text { Location: } \\
\text { Role: }\end{array}$} & \multicolumn{3}{|c|}{$\begin{array}{l}\text { Experiment I } \\
\text { Shanghai }\end{array}$} & \multirow{2}{*}{\multicolumn{2}{|c|}{$\begin{array}{l}\text { Experiment II } \\
\text { Ningbo } \\
\text { Students }\end{array}$}} \\
\hline & \multirow{2}{*}{$\begin{array}{l}\text { Students } \\
\text { Subjects } \\
\text { Employer }\end{array}$} & \multicolumn{2}{|c|}{ Migrant workers } & & \\
\hline & & $\begin{array}{l}\text { Subjects } \\
\text { Employee }\end{array}$ & Population & $\begin{array}{l}\text { Subjects } \\
\text { Employer/Employee }\end{array}$ & Population \\
\hline Anhui & 0.07 & 0.10 & 0.291 & 0.018 & 0.032 \\
\hline Beijing & & & 0.003 & & 0.016 \\
\hline Chongqing & & & 0.025 & & 0.026 \\
\hline Fujian & 0.06 & 0.00 & 0.030 & 0.018 & 0.025 \\
\hline Gansu & 0.01 & 0.00 & 0.010 & 0.008 & 0.014 \\
\hline Guangdong & 0.02 & 0.00 & 0.009 & 0.003 & 0.000 \\
\hline Guangxi & 0.00 & 0.00 & 0.005 & 0.011 & 0.021 \\
\hline Guizhou & 0.00 & 0.00 & 0.016 & 0.008 & 0.016 \\
\hline Hainan & 0.01 & 0.00 & 0.001 & 0.000 & 0.017 \\
\hline Hebei & 0.03 & 0.00 & 0.008 & 0.029 & 0.026 \\
\hline Heilongjiang & 0.03 & 0.01 & 0.011 & 0.058 & 0.072 \\
\hline Henan & 0.03 & 0.45 & 0.086 & 0.005 & 0.018 \\
\hline Hubei & 0.07 & 0.01 & 0.045 & 0.016 & 0.021 \\
\hline Hunan & 0.06 & 0.01 & 0.025 & 0.024 & 0.026 \\
\hline Jiangsu & 0.15 & 0.14 & 0.169 & 0.024 & 0.017 \\
\hline Jiangxi & 0.02 & 0.04 & 0.054 & 0.011 & 0.016 \\
\hline Jilin & 0.00 & 0.01 & 0.007 & 0.000 & 0.017 \\
\hline Liaoning & 0.01 & 0.00 & 0.007 & 0.029 & 0.029 \\
\hline Mongolia & 0.01 & 0.00 & 0.003 & 0.011 & 0.018 \\
\hline Ningxia & 0.02 & 0.00 & 0.001 & 0.000 & 0.013 \\
\hline Qinghai & 0.00 & 0.00 & 0.001 & 0.003 & 0.001 \\
\hline Shaanxi & 0.02 & 0.00 & 0.013 & 0.003 & 0.018 \\
\hline Shandong & 0.12 & 0.02 & 0.042 & 0.029 & 0.033 \\
\hline Shanghai & 0.12 & & & & 0.023 \\
\hline Shanxi & 0.01 & 0.00 & 0.005 & 0.013 & 0.017 \\
\hline Sichuan & 0.00 & 0.05 & 0.068 & 0.037 & 0.028 \\
\hline Tianjin & 0.01 & & 0.001 & & 0.039 \\
\hline Tibet & 0.00 & 0.00 & 0.000 & 0.000 & 0.000 \\
\hline Xinjiang & 0.01 & 0.01 & 0.003 & 0.000 & 0.015 \\
\hline Yunnan & 0.02 & 0.00 & 0.008 & 0.013 & 0.022 \\
\hline Zhejiang & 0.07 & 0.14 & 0.052 & 0.632 & 0.363 \\
\hline
\end{tabular}

Table gives the origins of our subjects and the population the employees were sampled from. The population of migrant workers is taken from the 2010 Chinese Population Census and gives the interprovincial floating population in Shanghai. $29.9 \%$ of the floating population in Shanghai comes from Shanghai, the remaining $70.1 \%$ originate from the provinces given in the table. In $2015,21.7 \%$ of the students at the University of Nottingham, Nigbo, were international students, the remaining $78.3 \%$ originated from China. The table gives the origins of the Chinese student population.

Table 7

Correlation between province characteristics.

\begin{tabular}{|c|c|c|c|c|c|}
\hline & Average wage origin & $\%$ NonHan origin & \% Rural origin & GRP & Unemployed \\
\hline \% NonHan Origin & $\begin{array}{l}r=0.4220 \\
p=0.0283\end{array}$ & & & & \\
\hline \% Rural Origin & $\begin{array}{l}r=-0.2147 \\
p=0.2821\end{array}$ & $\begin{array}{l}r=0.4435 \\
p=0.0205\end{array}$ & & & \\
\hline GRP & $\begin{array}{l}r=0.2999 \\
p=0.1286\end{array}$ & $\begin{array}{l}r=-0.5164 \\
p=0.0058\end{array}$ & $\begin{array}{l}r=-0.5465 \\
p=0.0032\end{array}$ & & \\
\hline Unemployed & $\begin{array}{l}r=-0.1286 \\
p=0.5226\end{array}$ & $\begin{array}{l}r=-0.6615 \\
p=0.001\end{array}$ & $\begin{array}{l}r=-0.4045 \\
p=0.0364\end{array}$ & $\begin{array}{l}r=0.7288 \\
p<0.001\end{array}$ & \\
\hline Population & $\begin{array}{l}r=-0.0278 \\
p=0.8906\end{array}$ & $\begin{array}{l}r=-0.6015 \\
p<0.001\end{array}$ & $\begin{array}{l}r=-0.2062 \\
p=0.3020\end{array}$ & $\begin{array}{l}r=0.8581 \\
p<0.001\end{array}$ & $\begin{array}{l}r=0.8499 \\
p<0.001\end{array}$ \\
\hline
\end{tabular}

Table reports coefficients and $p$-values for pairwise correlations between the variables from the complimentary field data. Calculations based on the 27 provinces included in this study. 
Table 8

Explaining the wage in the experiment.

\begin{tabular}{|c|c|c|c|c|c|c|}
\hline \multirow[t]{2}{*}{ Wage in experiment } & \multicolumn{3}{|c|}{ Students-migrant workers } & \multicolumn{3}{|c|}{ Students-students } \\
\hline & $(1)$ & $(2)$ & (3) & $(4)$ & (5) & (6) \\
\hline Average Wage Origin & $\begin{array}{l}0.400^{* * * * *} \\
(0.0623)\end{array}$ & $\begin{array}{l}0.338^{\text {***k* }} \\
(0.0715)\end{array}$ & $\begin{array}{l}0.175^{\text {*** }} \\
(0.0718)\end{array}$ & $\begin{array}{l}1.635^{\text {***** }} \\
(0.273)\end{array}$ & $\begin{array}{l}1.244^{\text {***** }} \\
(0.243)\end{array}$ & $\begin{array}{l}0.665^{\text {**** }} \\
(0.192)\end{array}$ \\
\hline Same Origin & $\begin{array}{l}0.502^{* * * k} \\
(0.211)\end{array}$ & $\begin{array}{l}0.437^{* *} \\
(0.212)\end{array}$ & $\begin{array}{l}0.382^{*} \\
(0.211)\end{array}$ & $\begin{array}{l}1.373^{* * * *} \\
(0.193)\end{array}$ & $\begin{array}{l}1.223^{* * * *} \\
(0.161)\end{array}$ & $\begin{array}{l}1.266^{* * * * *} \\
(0.146)\end{array}$ \\
\hline \% NonHan Origin & $\begin{array}{l}-1.231^{* * * *} \\
(0.121)\end{array}$ & 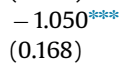 & $\begin{array}{l}-0.641^{* * * *} \\
(0.187)\end{array}$ & $\begin{array}{l}-3.749^{* * * *} \\
(0.497)\end{array}$ & $\begin{array}{l}-2.784^{* k \cdots k} \\
(0.509)\end{array}$ & $\begin{array}{l}-1.416^{* * * *} \\
(0.381)\end{array}$ \\
\hline \% Rural Origin & & $\begin{array}{c}-0.498 \\
(0.353)\end{array}$ & $\begin{array}{l}0.0419 \\
(0.433)\end{array}$ & & $\begin{array}{l}-3.306^{* * * *} \\
(1.033)\end{array}$ & $\begin{array}{l}-3.383^{\text {(1.*k:k }} \\
(1.110)\end{array}$ \\
\hline Trust in Origin & & $\begin{array}{l}0.0493^{* * *} \\
(0.0206)\end{array}$ & $\begin{array}{l}0.0476^{* *} \\
(0.0202)\end{array}$ & & $\begin{array}{l}0.101^{* * * *} \\
(0.0218)\end{array}$ & $\begin{array}{l}0.116^{\text {***k }} \\
(0.0193)\end{array}$ \\
\hline GRP/GDP & & & $\begin{array}{l}0.240^{* *} \\
(0.0957)\end{array}$ & & & $\begin{array}{l}0.580 \\
(0.390)\end{array}$ \\
\hline Central China & & & $\begin{array}{l}-0.277^{* * * k} \\
(0.0669)\end{array}$ & & & $\begin{array}{l}-0.175 \\
(0.229)\end{array}$ \\
\hline South China & & & $\begin{array}{l}-0.157^{* * *} \\
(0.0733)\end{array}$ & & & $\begin{array}{l}0.00481 \\
(0.230)\end{array}$ \\
\hline Western China & & & $\begin{array}{l}-0.268^{* * * *} \\
(0.0890)\end{array}$ & & & $\begin{array}{l}-0.602^{* * * * *} \\
(0.208)\end{array}$ \\
\hline Northeast China & & & $\begin{array}{c}-0.0708 \\
(0.0893)\end{array}$ & & & $\begin{array}{l}-0.644^{\text {*** }} \\
(0.258)\end{array}$ \\
\hline North China & & & $\begin{array}{l}-0.265^{* * *} \\
(0.0734)\end{array}$ & & & $\begin{array}{l}-0.722^{\text {*** }} \\
(0.278)\end{array}$ \\
\hline Constant & $\begin{array}{l}13.40^{* * * *} \\
(0.114)\end{array}$ & $\begin{array}{l}13.49^{* * * * *} \\
(0.323)\end{array}$ & $\begin{array}{l}13.52^{* * * *} \\
(0.351)\end{array}$ & $\begin{array}{l}11.65^{* * * * *} \\
(0.492)\end{array}$ & $\begin{array}{l}13.60^{\text {***k }} \\
(0.915)\end{array}$ & $\begin{array}{l}14.62^{\text {**k*k }} \\
(0.791)\end{array}$ \\
\hline Employer FE & Yes & Yes & Yes & Yes & Yes & Yes \\
\hline Observations & 2646 & 2646 & 2646 & 10,260 & 10,260 & 10,260 \\
\hline Subjects & 98 & 98 & 98 & 380 & 380 & 380 \\
\hline Prob $>F$ & $p<0.001$ & $p<0.001$ & $p<0.001$ & $p<0.0001$ & $p<0.0001$ & $p<0.001$ \\
\hline
\end{tabular}

Table reports regressions of wage decisions by employers on employees' province characteristics. All columns give panel regressions with employer fixed effects and robust clusters on the level of the province the wage was assigned to.

$$
\begin{aligned}
& * * * * \quad p<0.01 \\
& * * * 1 \\
& * p<0.05 \\
& *<0.1
\end{aligned}
$$

\begin{tabular}{|c|c|c|c|}
\hline Wage in experiment & (1) & $(2)$ & (3) \\
\hline Average Wage Origin & $\begin{array}{l}0.400^{* * * * *} \\
(0.0623)\end{array}$ & $\begin{array}{l}1.635^{* * * *} \\
(0.273)\end{array}$ & $\begin{array}{l}1.635^{\text {***** }} \\
(0.273)\end{array}$ \\
\hline Average Wage Origin $\times$ Migrantworker & & & $\begin{array}{l}-1.235^{* * *} \\
(0.267)\end{array}$ \\
\hline Same Origin & $\begin{array}{l}0.502^{* * *} \\
(0.211)\end{array}$ & $\begin{array}{l}1.373^{* * * *} \\
(0.193)\end{array}$ & $\begin{array}{l}1.373^{* * * *} \\
(0.193)\end{array}$ \\
\hline Same Origin $\times$ Migrantworker & & & $\begin{array}{l}-0.871^{* * *} \\
(0.337)\end{array}$ \\
\hline \% NonHan Origin & $\begin{array}{l}-1.231^{* * * *} \\
(0.121)\end{array}$ & $\begin{array}{l}-3.749^{* * * k} \\
(0.497)\end{array}$ & $\begin{array}{l}-3.749^{* * * * *} \\
(0.497)\end{array}$ \\
\hline$\%$ NonHan Origin $\times$ Migrantworker & & & 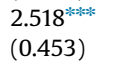 \\
\hline Constant & $\begin{array}{l}13.40^{* * * * *} \\
(0.114)\end{array}$ & $\begin{array}{l}11.65^{* * * *} \\
(0.492)\end{array}$ & $\begin{array}{l}12.01^{* * * *} \\
(0.400)\end{array}$ \\
\hline Sample employee: & Migrantworker & Student & Both \\
\hline Observations & 2646 & 10,260 & 12,906 \\
\hline Number of subjects & 98 & 380 & 478 \\
\hline Prob $>F$ & $p<0.001$ & $p<0.001$ & $p<0.001$ \\
\hline
\end{tabular}

Table 9

Explaining the wage in the experiment.

Table reports regressions of wage decisions by employers on employees' province characteristics. All columns give panel regressions with employer fixed effects and robust clusters on the level of the province the wage was assigned to. Model 1 includes only wages assigned to migrant workers (Experiment I), Model 2 only wages assigned to students (Experiment II), and Model 3 the data from both Experiments. Migrantworker is a dummy variable with a value of one if the employer is matched with migrant workers.

$$
\begin{aligned}
& * * * * p<0.01 \\
& * * * \\
& *<0.05 \\
& * p<0.1
\end{aligned}
$$


Table 10

Classification of individual's discrimination patterns.

\begin{tabular}{|c|c|c|c|c|}
\hline & \multicolumn{2}{|c|}{ Experiment I } & \multicolumn{2}{|c|}{ Experiment II } \\
\hline & Numbers & Share & Numbers & Share \\
\hline \multicolumn{5}{|l|}{ A. Discriminating subjects } \\
\hline Subject discriminates at all & $55 / 98$ & 0.561 & $371 / 380$ & 0.976 \\
\hline Subjects' discrimination pattern not identified & $4 / 55$ & 0.073 & $24 / 371$ & 0.065 \\
\hline Subjects' discrimination pattern identified & $51 / 55$ & 0.927 & $347 / 371$ & 0.935 \\
\hline \multicolumn{5}{|c|}{ B. Subjects influenced by Average Wage Origin, Same Origin or \% NonHan Origin } \\
\hline Based on only one characteristics & $18 / 55$ & 0.353 & $94 / 347$ & 0.271 \\
\hline a. Average Wage Origin & 3 & 0.059 & 16 & 0.046 \\
\hline b. Same Origin & 14 & 0.275 & 55 & 0.159 \\
\hline c. \% NonHan Origin & 1 & 0.020 & 23 & 0.066 \\
\hline Based on two characteristics & $18 / 55$ & 0.353 & $171 / 347$ & 0.493 \\
\hline a. Average Wage Origin and \% NonHan Origin & 6 & 0.118 & 117 & 0.337 \\
\hline b. Average Wage Origin and Same Origin & 3 & 0.059 & 12 & 0.035 \\
\hline c. \% NonHan Origin and Same Origin & 9 & 0.176 & 42 & 0.121 \\
\hline Based on all three characteristics & $15 / 55$ & 0.294 & $82 / 347$ & 0.236 \\
\hline
\end{tabular}

To classify the individual type of discrimination, we run for each employer a linear regression. Separately for each employer, we regress $w_{p}=y_{0}+y_{1} c_{1 p}+y_{2} c_{2 p}+y_{3} c_{3 p}+\epsilon_{p}$ with $w_{p}$ being the assigned wage to a province and $c_{1 p}, c_{2 p}$ and $c_{3 p}$ being the characteristics Average Wage Origin, Same Origin, and \% NonHan Origin. If an estimated coefficient is significant on at least the $10 \%$ level we classify this employer as someone who discriminates based on this motive.

\section{Appendix D. Additional robustness checks}

\section{D.1. Additional controls: population and unemployment}

In the regressions reported in the paper we do not control for population size and unemployment in the employees' home provinces as they do not improve the fit of the reported model. For completeness we report the estimations when both are included as additional controls. Fig. 7 gives the distribution of the population sizes and unemployment numbers for the 27 provinces and regions. Table 11 reports the resulting estimates when controlling for population and unemployment.

Neither are the coefficients for population and unemployment significant nor do they substantially improve the $R^{2}$. In Experiment I the $R^{2}$ remains unchanged; in Experiment II it is improved by merely $0.06 \%$. The coefficients of our three main explanatory variables remain relatively stable suggesting that our estimation does not suffer from omitted variable bias. However, ruralness is highly correlated with the two variables and because of multicollinearity its effect turns insignificant.

\section{D.2. Additional controls: differences in ruralness}

The perceived ruralness of an employee's home province could potentially be influenced by the ruralness of the employer's home province. In the following we run random-effects regressions with our full set of controls adding the
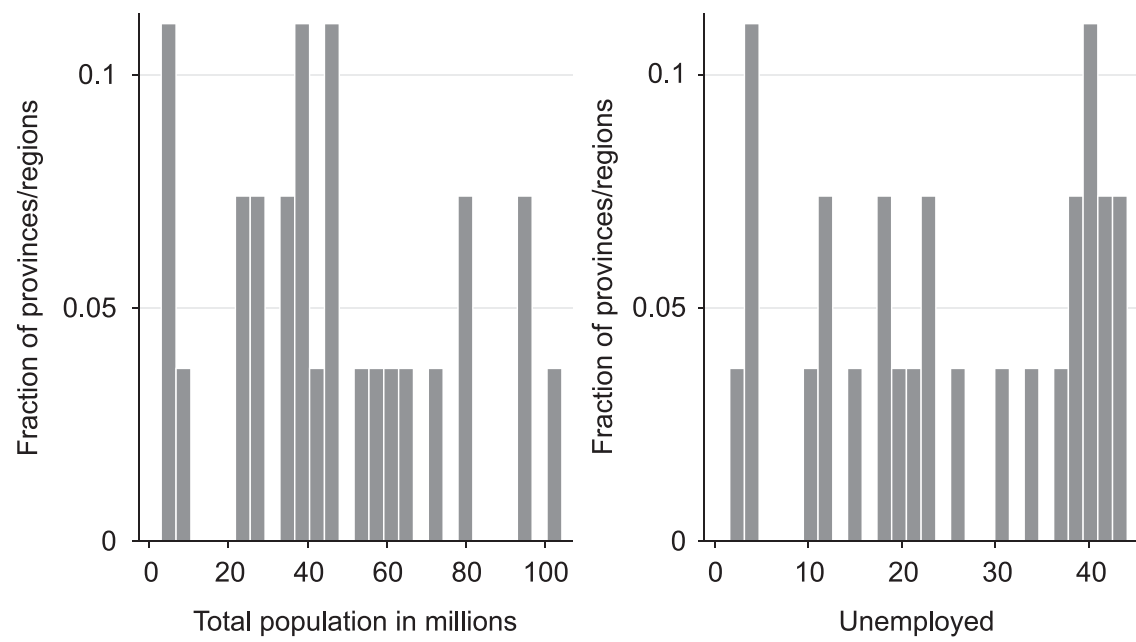

Fig. 7. Population and unemployment in the 27 provinces/regions 
Table 11

Explaining the wage in the experiment.

\begin{tabular}{|c|c|c|c|c|}
\hline \multirow[t]{2}{*}{ Wage in experiment } & \multicolumn{2}{|c|}{ Students-migrant workers } & \multicolumn{2}{|c|}{ Students-students } \\
\hline & (1) & $(2)$ & (3) & $(4)$ \\
\hline Average Wage Origin & 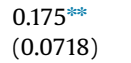 & $\begin{array}{l}0.181^{\text {***k }} \\
(0.0662)\end{array}$ & $\begin{array}{l}0.665^{* * * * *} \\
(0.192)\end{array}$ & $\begin{array}{l}0.648^{* * * * *} \\
(0.218)\end{array}$ \\
\hline Same Origin & $\begin{array}{l}0.382^{*} \\
(0.211)\end{array}$ & $\begin{array}{l}0.383^{*} \\
(0.212)\end{array}$ & $\begin{array}{l}1.266^{* * * * *} \\
(0.146)\end{array}$ & $\begin{array}{l}1.270 \text { **** } \\
(0.140)\end{array}$ \\
\hline \% NonHan Origin & 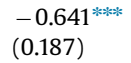 & $\begin{array}{l}-0.621^{* * *} \\
(0.256)\end{array}$ & $\begin{array}{l}-1.416^{\text {***** }} \\
(0.381)\end{array}$ & 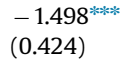 \\
\hline \% Rural Origin & $\begin{array}{l}0.0419 \\
(0.433)\end{array}$ & $\begin{array}{l}-0.0238 \\
(0.849)\end{array}$ & $\begin{array}{l}-3.383^{* * * * *} \\
(1.110)\end{array}$ & $\begin{array}{l}-2.932 \\
(2.080)\end{array}$ \\
\hline Trust in Origin & $\begin{array}{l}0.0476^{* *} \\
(0.0202)\end{array}$ & $\begin{array}{l}0.0474 \text { * } \\
(0.0201)\end{array}$ & $\begin{array}{l}0.116^{* * * * *} \\
(0.0193)\end{array}$ & $\begin{array}{l}0.115^{* * * * *} \\
(0.0180)\end{array}$ \\
\hline Population & & $\begin{array}{l}6.92 e-05 \\
(0.00453)\end{array}$ & & $\begin{array}{l}-0.00297 \\
(0.0137)\end{array}$ \\
\hline Unemployed & & $\begin{array}{l}0.00172 \\
(0.00388)\end{array}$ & & $\begin{array}{l}5.68 \mathrm{e}-05 \\
(0.0152)\end{array}$ \\
\hline Constant & $\begin{array}{l}13.52^{* * * * *} \\
(0.351)\end{array}$ & $\begin{array}{l}13.53^{* * * * * *} \\
(0.520)\end{array}$ & $\begin{array}{l}14.62^{* * * * *} \\
(0.791)\end{array}$ & $\begin{array}{l}14.43^{* * * * *} \\
(1.271)\end{array}$ \\
\hline Additional Controls & Yes & Yes & Yes & Yes \\
\hline Employer FE & Yes & Yes & Yes & Yes \\
\hline Observations & 2646 & 2646 & 110,260 & 10,260 \\
\hline Subjects & 98 & 98 & 380 & 380 \\
\hline$R^{2}$ overall & 0.0097 & 0.0097 & 0.1558 & 0.1559 \\
\hline Prob $>F$ & $p<0.001$ & $p<0.001$ & $p<0.0001$ & $p<0.001$ \\
\hline
\end{tabular}

Table reports regressions of wage decisions by employers on employees' province characteristics. All columns give panel regressions with employer fixed effects and robust clusters on the level of the province the wage was assigned to. Additional controls are the gross regional product relative to the gross domestic product and region dummies (Central China, East China, South China, Western China, North China, and Northeast China).

$$
\begin{aligned}
& * * * * 0<0.01 \\
& * * * 0.05 \\
& * p<0.1
\end{aligned}
$$

\begin{tabular}{|c|c|c|c|c|}
\hline \multirow[t]{2}{*}{ Wage in experiment } & \multicolumn{2}{|c|}{ Students-migrant workers } & \multicolumn{2}{|c|}{ Students-students } \\
\hline & (1) & $(2)$ & (3) & (4) \\
\hline Average Wage Origin & $\begin{array}{l}0.175^{* * *} \\
(0.0719)\end{array}$ & $\begin{array}{l}0.175^{* * *} \\
(0.0719)\end{array}$ & $\begin{array}{l}0.664^{* * * * *} \\
(0.192)\end{array}$ & $\begin{array}{l}0.664^{* * * * *} \\
(0.192)\end{array}$ \\
\hline Same Origin & $\begin{array}{l}0.384^{*} \\
(0.219)\end{array}$ & $\begin{array}{l}0.384^{*} \\
(0.219)\end{array}$ & $\begin{array}{l}1.274^{* * * *} \\
(0.145)\end{array}$ & $\begin{array}{l}1.274^{* * * * *} \\
(0.146)\end{array}$ \\
\hline \% NonHan Origin & 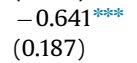 & $\begin{array}{l}-0.641^{\text {****** }} \\
(0.187)\end{array}$ & $\begin{array}{l}-1.417^{\text {***** }} \\
(0.382)\end{array}$ & 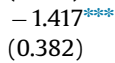 \\
\hline \% Rural Origin & $\begin{array}{l}0.0416 \\
(0.432)\end{array}$ & $\begin{array}{l}0.897 \\
(1.635)\end{array}$ & $\begin{array}{l}-3.389^{* * \cdots * k} \\
(1.110)\end{array}$ & $\begin{array}{l}-3.501 \text { *** } \\
(1.476)\end{array}$ \\
\hline Difference Rural & & $\begin{array}{l}-0.855 \\
(1.569)\end{array}$ & & $\begin{array}{l}0.112 \\
(0.957)\end{array}$ \\
\hline Constant & $\begin{array}{l}13.52^{* * * * *} \\
(0.425)\end{array}$ & 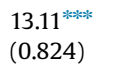 & 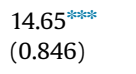 & 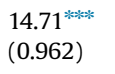 \\
\hline Additional Controls & Yes & Yes & Yes & Yes \\
\hline Observations & 2646 & 2646 & 110,260 & 10,260 \\
\hline Subjects & 98 & 98 & 380 & 380 \\
\hline Prob $>F$ & $p<0.001$ & $p<0.001$ & $p<0.0001$ & $p<0.001$ \\
\hline
\end{tabular}

\section{Table 12}

Explaining the wage in the experiment.

Table reports regressions of wage decisions by employers on employees' province characteristics. All columns give panel regressions with random effects and robust clusters on the level of the province the wage was assigned to. Additional controls are the gross regional product relative to the gross domestic product and region dummies (Central China, East China, South China, Western China, North China, and Northeast China).

$$
\begin{aligned}
& * * * * * 0<01 \\
& * * x<0.05 \\
& * p<0.1
\end{aligned}
$$


difference in rural population as an additional control. Our previously reported results remain unchanged, the difference in ruralness does not influence the wage decision in our experiments.

\section{D.3. Additional controls: socio-economic order}

The positive influence on assigned wages could be caused by average wage levels being correlated with a possible ranking of provinces along socio-economic status. We, therefore, test whether our results remain robust if we include variables that could capture such a possible ranking. Table 13 gives the results of these additional robustness checks for Experiment I and Experiment II. Models 1 and 6 repeat the last estimates from the main text with employer fixed effects and controls for trust towards province, percentage of the rural population, the gross regional products in relation to the gross domestic product, and region dummies for Central China, East China, South China, Western China, North China, and Northeast China.

In Models 2 and 7, we add the ranking of provinces according to the average wage levels as a discrete variable (Ranking Average Wages). To allow for nonlinearities, we add dummy variables for the quantiles of the wage ranking in Models 3 and 8. In Models 4 and 9, we use a ranking of provinces according to the gross regional product as a discrete variable (Ranking $G R P)$. And again, to allow for nonlinearities we include dummy variables for the quantiles of the gross regional product ranking in Models 5 and 10.

While all these variables are correlated with the average wage levels in the provinces, they do not impact the originally reported effect of Average Wage Origin on assigned wages in the experiments. The levels of significance remain at conventional levels and the coefficients remain qualitatively similar. In fact, the largest changes are observed when controlling for the ranking of wage levels, but the ranking actually increase the estimates for Average Wage Origin instead of reducing them. This implies that the Average Wage Origin explains the assigned wages better than socio-economic rankings based on wage levels or gross regional product.

\section{D.4. Additional controls: strategy method}

The exclusion of the municipalities (Beijing, Chongqing, Shanghai, and Tianjin) was based on the rationale that it would be very unlikely for a migrant worker to move from Beijing to Shanghai. However, the number of employees coming from the remaining provinces differs quite substantially between the provinces. Table 6 gives the distribution of home provinces in our experiments for employers and employees. In Experiment I, most migrant workers originated from Henan (45\%),

Table 13

Explaining the wage in the experiment.

\begin{tabular}{|c|c|c|c|c|c|c|c|c|c|c|}
\hline \multirow[t]{2}{*}{ Wage in experiment } & \multicolumn{5}{|c|}{ Experiment I: Students-migrant workers } & \multicolumn{5}{|c|}{ Experiment II: Students-students } \\
\hline & $(1)$ & $(2)$ & (3) & (4) & (5) & (6) & (7) & (8) & (9) & $(10)$ \\
\hline Average Wage Origin & $\begin{array}{l}0.175^{* *} \\
(0.0718)\end{array}$ & $\begin{array}{l}0.239^{* * *} \\
(0.0933)\end{array}$ & $\begin{array}{l}0.352^{\text {***** }} \\
(0.103)\end{array}$ & $\begin{array}{l}0.180^{\text {**k }} \\
(0.0668)\end{array}$ & $\begin{array}{l}0.145^{\text {*** }} \\
(0.0679)\end{array}$ & $\begin{array}{l}0.665^{\text {***** }} \\
(0.192)\end{array}$ & $\begin{array}{l}0.908^{* * * *} \\
(0.288)\end{array}$ & $\begin{array}{l}0.894^{\text {冰冰 }} \\
(0.227)\end{array}$ & $\begin{array}{l}0.684^{\text {***** }} \\
(0.185)\end{array}$ & $\begin{array}{l}0.585^{\text {***** }} \\
(0.171)\end{array}$ \\
\hline Same Origin & $\begin{array}{l}0.383^{*} \\
(0.211)\end{array}$ & $\begin{array}{l}0.392^{*} \\
(0.211)\end{array}$ & $\begin{array}{l}0.388^{*} \\
(0.213)\end{array}$ & $\begin{array}{l}0.385^{*} \\
(0.211)\end{array}$ & $\begin{array}{l}0.384^{*} \\
(0.212)\end{array}$ & $\begin{array}{l}1.266^{\text {****k }} \\
(0.146)\end{array}$ & $\begin{array}{l}1.225^{\text {***** }} \\
(0.145)\end{array}$ & $\begin{array}{l}1.220^{* * k * k} \\
(0.155)\end{array}$ & $\begin{array}{l}1.224^{* * * * *} \\
(0.154)\end{array}$ & $\begin{array}{l}1.165^{* * * *} \\
(0.165)\end{array}$ \\
\hline$\%$ NonHan Origin & 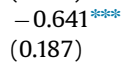 & $\begin{array}{l}-0.620^{* * * * *} \\
(0.177)\end{array}$ & $\begin{array}{l}-0.689^{* * * * *} \\
(0.16)\end{array}$ & $\begin{array}{l}-0.608^{* * * k * k} \\
(0.186)\end{array}$ & $\begin{array}{l}-0.531^{\text {**** }} \\
(0.189)\end{array}$ & $\begin{array}{l}-1.416^{\text {**k*k }} \\
(0.381)\end{array}$ & $\begin{array}{l}-1.348^{* k_{k} \cdot k} \\
(0.344)\end{array}$ & $\begin{array}{l}-1.455^{\text {**** }} \\
(0.327)\end{array}$ & $\begin{array}{l}-1.358^{* * * * k} \\
(0.349)\end{array}$ & 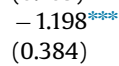 \\
\hline Ranking Average Wages & & $\begin{array}{c}-0.00478 \\
(0.00497)\end{array}$ & & & & & $\begin{array}{c}-0.017 \\
(0.0161)\end{array}$ & & & \\
\hline Ranking GRP & & & & $\begin{array}{l}0.00779 \\
(0.00641)\end{array}$ & & & & & $\begin{array}{l}0.0151 \\
(0.0214)\end{array}$ & \\
\hline Constant & $\begin{array}{l}13.52^{\text {*冰水 }} \\
(0.351\end{array}$ & $\begin{array}{l}13.50^{\text {***** }} \\
(0.341)\end{array}$ & $\begin{array}{l}13.43^{\text {**** }} \\
(0.32)\end{array}$ & $\begin{array}{l}13.49^{* * * *} \\
(0.338)\end{array}$ & $\begin{array}{l}13.66^{\text {秋水 }} \\
(0.406)\end{array}$ & $\begin{array}{l}14.62^{\text {****k }} \\
(0.791)\end{array}$ & $\begin{array}{l}14.54^{\text {*冰水 }} \\
(0.783)\end{array}$ & $\begin{array}{l}14.53^{\text {****k }} \\
(0.706)\end{array}$ & $\begin{array}{l}14.55^{\text {***** }} \\
(0.764)\end{array}$ & $\begin{array}{l}15.18^{\text {*冰水 }} \\
(0.866)\end{array}$ \\
\hline Average Wage Quantile & No & No & Yes & No & No & No & No & Yes & No & No \\
\hline GRP Quantile & No & No & No & No & Yes & No & No & No & No & Yes \\
\hline Additional Controls & Yes & Yes & Yes & Yes & Yes & Yes & Yes & Yes & Yes & Yes \\
\hline Employer FE & Yes & Yes & Yes & Yes & Yes & Yes & Yes & Yes & Yes & Yes \\
\hline Observations & 2646 & 2646 & 2646 & 2646 & 2646 & 10,260 & 10,260 & 10,260 & 10,260 & 10,260 \\
\hline Number of UID & 98 & 98 & 98 & 98 & 98 & 380 & 380 & 380 & 380 & 380 \\
\hline Prob $>F$ & $p<0.001$ & $p<0.001$ & $p<0.001$ & $p<0.001$ & $p<0.001$ & $p<0.001$ & $p<0.001$ & $p<0.001$ & $p<0.001$ & $p<0.001$ \\
\hline
\end{tabular}

Table reports regressions of wage decisions by employers on employees' province characteristics. All columns give panel regressions with employer fixed effects and robust clusters on the level of the province the wage was assigned to. Additional controls are trust towards province, ruralness of province, the gross regional product relative to the gross domestic product and region dummies (Central China, East China, South China, Western China, North China, and Northeast China).

$* * * * 0.01$.

$* * *<0.05$

* $p<0.1$. 
Table 14

Explaining the wage in the experiment.

\begin{tabular}{|c|c|c|c|c|c|c|c|c|}
\hline \multirow[t]{2}{*}{ Wage in experiment } & \multicolumn{4}{|c|}{ Experiment I: Students-migrant workers } & \multicolumn{4}{|c|}{ Experiment II: Students-students } \\
\hline & $(1)$ & $(2)$ & (3) & (4) & (5) & (6) & (7) & $(8)$ \\
\hline Average Wage Origin & $\begin{array}{l}0.175^{\text {*** }} \\
(0.0718)\end{array}$ & $\begin{array}{l}0.333^{* * * *} \\
(0.0954)\end{array}$ & $\begin{array}{l}0.203^{\text {*** }} \\
(0.0805)\end{array}$ & $\begin{array}{l}0.188^{\text {*** }} \\
(0.0730)\end{array}$ & $\begin{array}{l}0.665^{\text {***** }} \\
(0.192)\end{array}$ & $\begin{array}{l}0.882^{*} \\
(0.450)\end{array}$ & $\begin{array}{l}0.579^{* * * *} \\
(0.202)\end{array}$ & 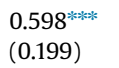 \\
\hline Same Origin & $\begin{array}{l}0.382^{*} \\
(0.211)\end{array}$ & $\begin{array}{l}0.359 \\
(0.217)\end{array}$ & $\begin{array}{l}0.382^{*} \\
(0.212)\end{array}$ & $\begin{array}{l}0.387^{*} \\
(0.212)\end{array}$ & $\begin{array}{l}1.266^{\text {**k*k }} \\
(0.146)\end{array}$ & $\begin{array}{l}1.166^{* * *} \\
(0.149)\end{array}$ & $\begin{array}{l}1.100^{* * k * k} \\
(0.123)\end{array}$ & $\begin{array}{l}1.112^{* * * * \cdot k} \\
(0.128)\end{array}$ \\
\hline \% NonHan Origin & $\begin{array}{l}-0.641^{\text {*k*** }} \\
(0.187)\end{array}$ & $\begin{array}{l}-0.559^{*} \\
(0.111)\end{array}$ & $\begin{array}{l}-0.691^{\text {*k*k }} \\
(0.207)\end{array}$ & $\begin{array}{l}-0.685^{\text {*k*k }} \\
(0.208)\end{array}$ & $\begin{array}{l}-1.416^{* * * *} \\
(0.381)\end{array}$ & $\begin{array}{l}-1.343^{*} \\
(0.755)\end{array}$ & $\begin{array}{l}-1.306^{* * * *} \\
(0.385)\end{array}$ & 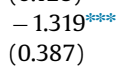 \\
\hline$\%$ in Sample & & & $\begin{array}{l}-0.368^{*} \\
(0.185)\end{array}$ & & & & $\begin{array}{l}0.594 \\
(0.457)\end{array}$ & \\
\hline \% in Population & & & & $\begin{array}{l}-0.468 \\
(0.337)\end{array}$ & & & & $\begin{array}{l}0.958 \\
(0.772)\end{array}$ \\
\hline Constant & $\begin{array}{l}13.52^{\text {**** }} \\
(0.351)\end{array}$ & $\begin{array}{l}13.13^{* * * * *} \\
(0.530)\end{array}$ & $\begin{array}{l}13.38^{* * * *} \\
(0.381)\end{array}$ & 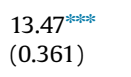 & $\begin{array}{l}14.62^{* * * *} \\
(0.791)\end{array}$ & $\begin{array}{l}14.05^{\text {**** }} \\
(1.705)\end{array}$ & $\begin{array}{l}14.67^{* * * * *} \\
(0.767)\end{array}$ & $\begin{array}{l}14.63^{* * * *} \\
(0.783)\end{array}$ \\
\hline Additional Controls & Yes & Yes & Yes & Yes & Yes & Yes & Yes & Yes \\
\hline Employer FE & Yes & Yes & Yes & Yes & Yes & Yes & Yes & Yes \\
\hline Sample & Full & Origin in sample & Full & Full & Full & Origin in sample & Full & Full \\
\hline Observations & 2646 & 1176 & 2646 & 2646 & 10,260 & 8360 & 10,260 & 10,260 \\
\hline Number of UID & 98 & 98 & 98 & 98 & 380 & 380 & 380 & 380 \\
\hline Prob $>F$ & $p<0.001$ & $p<0.001$ & $p<0.001$ & $p<0.001$ & $p<0.001$ & $p<0.001$ & $p<0.001$ & $p<0.001$ \\
\hline
\end{tabular}

All columns give panel regressions with employer fixed effects and robust clusters on the level of the province the wage was assigned to. Additional controls are trust towards province, ruralness of province, the gross regional product relative to the gross domestic product and region dummies (Central China, East China, South China, Western China, North China, and Northeast China).

$* * * * \quad p<0.01$.

*** $p<0.05$.

$* p<0.1$.

Zheijiang (14\%), and Jiangsu (14\%). In Experiment II, most students originated from Zheijiang (63\%), Heilongjiang (5.8\%), and Sichuan (3.7\%). In both experiments, there were provinces from which no subject originated (e.g., Tibet in both experiments). Thus, some wage decisions were more likely to be realized for the payments than others. This naturally raises the question if all responses were equally well incentivized and all decisions made with the same seriousness. In Table 14 we present additional robustness checks. Models 1 and 5 present the results from the main paper with employer fixed effects and the full set of controls for trust towards province, percentage of the rural population, the gross regional products in relation to the gross domestic product, and region dummies. In Models 2 and 6, we apply the most rigorous robustness check by dropping all provinces from which no employee originated in the corresponding experiment. This reduces the sample in Experiment I by more than 50\%. The $p$-value for Same Origin drops to $p=0.127$ while the $p$-values for Average Wage Origin and \% NonHan Origin remain on conventional levels of significance. In Experiment II this reduces the sample by $18.5 \%$ but the $p$-values for our main coefficients Average Wage Origin, Same Origin, and \% NonHan Origin remain on conventional levels. In Models 3, 4, 7, and 8 we keep the whole sample, but include either the variable \% In Sample or \% In Population to control for the likelihood of being matched with someone from a province. \% In Sample bases the probability on the distribution in the sample while \% In Population bases the probability on the populations from which the samples were drawn (see Table 6). Results are qualitatively in line with our originally reported results and all effects are on the same levels of significance as in Models 1 and 5. Therefore, we conclude that our main effects are qualitatively not influenced by the actual distribution of employee's home provinces in our sample.

\section{D.5. Additional controls: influences on second stage behavior}

In Experiment II subjects first decided in the role of employers and then decided in the role of employees. While they did not receive feedback after the first stage it is still possible that the first stage behavior influenced the second stage behavior. In Table 15 we add controls for their first stage decisions. The variable Employer: Wage assigned is the wage the subject assigned to employees from the same province in the first stage. Employer: Discriminated is a dummy variable which values turns one if the subject discriminated as an employer. Neither do these two variables influence the decision to exert high effort, nor does the inclusion change any of the previously reported non-results. 
Table 15

Explaining the effort in Experiment II.

\begin{tabular}{|c|c|c|c|c|}
\hline Prob(High Effort) & $(1)$ & $(2)$ & (3) & $(4)$ \\
\hline \multirow[t]{2}{*}{ Wage in experiment } & $1.0343^{* * * *}$ & $1.0343^{* * * *}$ & $1.0343^{* * *}$ & $1.0343^{* * * *}$ \\
\hline & $(0.038)$ & $(0.038)$ & $(0.038)$ & $(0.038)$ \\
\hline \multirow[t]{2}{*}{ Worker's origin real wage } & -0.1559 & -0.1283 & -0.1563 & -0.1282 \\
\hline & $(0.413)$ & $(0.417)$ & $(0.413)$ & $(0.417)$ \\
\hline \multirow[t]{2}{*}{ Worker's origin \% NonHan } & 2.9427 & 2.8764 & 2.9461 & 2.8811 \\
\hline & $(2.082)$ & $(2.087)$ & $(2.083)$ & $(2.087)$ \\
\hline \multirow[t]{2}{*}{ Worker's origin \% Rural } & -4.0650 & -4.1274 & -4.0809 & -4.1616 \\
\hline & $(2.582)$ & $(2.585)$ & $(2.596)$ & $(2.601)$ \\
\hline \multirow[t]{2}{*}{ Worker female } & -0.2532 & -0.2649 & -0.2525 & -0.2638 \\
\hline & $(0.289)$ & $(0.290)$ & $(0.289)$ & $(0.290)$ \\
\hline \multirow[t]{2}{*}{ Worker's age } & 0.0038 & 0.0036 & 0.0037 & 0.0035 \\
\hline & $(0.014)$ & $(0.014)$ & $(0.014)$ & $(0.014)$ \\
\hline \multirow[t]{2}{*}{ Employer: Wage assigned } & & -0.0226 & & -0.0234 \\
\hline & & $(0.048)$ & & $(0.048)$ \\
\hline \multirow[t]{2}{*}{ Employer: Discriminated } & & & 0.1023 & 0.2075 \\
\hline & & & $(1.721)$ & $(1.735)$ \\
\hline \multirow[t]{2}{*}{ Constant } & $-14.5151^{* * * *}$ & $-14.1575^{* * * *}$ & $-14.5075^{* * * *}$ & 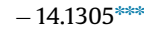 \\
\hline & $(2.178)$ & $(2.304)$ & $(2.182)$ & $(2.315)$ \\
\hline Observations & 3800 & 3800 & 3800 & 3800 \\
\hline Number of UID & 380 & 380 & 380 & 380 \\
\hline Prob $>\chi^{2}$ & 0 & 0 & 0 & 0 \\
\hline
\end{tabular}

Random-effects logistic regression explaining effort decision in Experiment II.

**** $p<0.01$.

$* * p<0.05$

$* p<0.1$.

\section{Appendix E. A model}

Here we introduce a formal model describing the employees' $(E)$ and the employers' $(R)$ decision. The model is designed to resemble as closely as possible the environment for the participants of the experiment.

\section{E.1. Decision structure, timing, and beliefs}

The timing of the moves mirrors the experiment described in Section 2 of the paper and Appendix A. Upon meeting, employee $i$ reveals his origin, i.e., in which province $P$ employee $i$ was born. This is the only piece of information that is exchanged. After learning the employee's origin $p_{i} \in P$, the employer forms beliefs $F_{j}$ about the lowest wage $w_{i}^{F}\left(a_{i}, p_{i}\right)$ that the employee regards as a fair compensation for working hard, where $a_{i}$ denotes additional, exogenous information such as the average wage in a certain province or the share of Non-Han Chinese living in the province. On the basis of these beliefs, the employer will offer employee $i$ a wage $w_{j}$. The wage $w_{j}$ can take values on the interval $\left[w^{\min }, w^{\max }\right]=[11,20]$ in our experiment. After the employer made the wage offer, the employee decides on whether to work hard $\left(e_{i}=1\right)$ or normal $\left(e_{i}=0\right)$.

We follow Akerlof (1982) in assuming that employees compare wage offers $w_{j}$ to what they regard as a fair compensation for a high effort. Naturally, the notion of a fair compensation e.g. depends on previously received wages, unemployment benefits, work norms and wages paid to reference groups. While most of Akerlof's determinants of a fair wage are irrelevant in our setting, wages paid to a reference group are highly relevant and are derived from the average wage levels in the home province $p_{i}$ of worker $i$. After all, a migrant worker would only move to a different province if s/he expects to earn more than in her home province. The precise functional relationship between the actual wage level in the home province and the wage level $w_{i}^{F}$ worker $i$ regards as a fair compensation is unknown and may differ between individuals from the same province. However, it is reasonable to assume that $w_{i}^{F}$ increases with the average wage level in province $p_{i}$.

Employers are aware that employees are only willing to exert a high work effort if the employer offers a wage higher than the employee's notion of a fair wage $w_{i}^{F}(\cdot)$. However, the only piece of information exchanged prior to the wage offer is the home province of the employee $i$. Therefore, employers form their beliefs $F_{j}$ about employee $i$ 's notion of a fair wage on the information of the home province $p_{i}$ and the associated publicly available information about this home province, such as the average wage, the share of Non-Han Chinese or the unemployment rate. Assume that employee $i$ is prepared to work hard for wages $w_{j} \geq w_{i}^{F}(\cdot)$. Then, $F_{j}^{p_{i}}\left(w_{j} ; \cdot\right)$ denotes the probability that the wage offer $w_{j}$ indeed exceeds $i$ 's notion of a fair wage $w_{i}^{F}(\cdot)$. We impose only one restriction upon the employers' beliefs, the beliefs $F_{j}^{p_{i}}\left(w_{j} ; \cdot\right)$ are strictly unimodal with an expected value $\mu_{j}^{p_{i}}=\mu_{j}\left(a\left(p_{i}\right)\right)$ and variance $\sigma_{j}^{p_{i}}$. Hence, employer $j$ forms beliefs about the expected value of employee $i$ 's fair wage on the basis of publicly available information about the province $p_{i}$. Consequently, expected fair wage levels $\mu_{j}^{p_{i}}$ will differ depending on the migrant workers' home province. We allow each employer $j$ to form his/her own beliefs upon the expected fair wage $\mu_{j}^{p_{i}}$ as well as the accuracy of their beliefs, $\sigma_{j}^{p_{i}}$, i.e., two employers may well disagree about $\mu_{j}^{p_{i}}$ and $\sigma_{i}^{p_{i}}$. 


\section{E.2. Employees' decision}

Given the decision structure, information and timing as described above, it is clear that the notion about what constitutes a fair wage is unique to each individual employee. Of course we assume that certain patterns can be observed as, e.g., a positive correlation between the average wage in a province and the fair wage. However two employees from the same province do not necessarily have the same fair wage.

The basis of any gift exchange as described above is that the recipient of the initial gift derives a positive utility from reciprocal behavior. We therefore follow Falk and Fischbacher (2006) in modifying the employees' objective function to allow for reciprocal behavior. Let employee $i$ 's objective function be given by

$$
U_{i}^{E}\left(e_{i}, w_{j}, w_{i}^{F}(\cdot)\right)=\pi_{i}^{E}+\rho_{i}\left(w_{j}-w_{i}^{F}(\cdot)\right) \pi_{j}^{R},
$$

where $\pi_{i}^{E}$ and $\pi_{j}^{R}$ are the payoffs for employee $i$ and employer $j$ respectively. $\rho_{i}$ is a positive constant which measures the strength of $i$ 's reciprocal feelings, i.e., the second expression on the right hand side of the objective function. The reciprocal component itself is comprised of what Falk and Fischbacher (2006) call the kindness term, here $w_{j}-w_{i}^{F}(\cdot)$, and the reciprocation term, here $\pi_{j}^{R}$.

After the employer made a specific wage offer $w_{j}$, the employee decides on the effort s/he wants to exert. Given the employee's utility function, the employee will work hard only if

$$
\Delta U_{i}^{E}:=U_{i}^{E}\left(e_{i}=1, w_{j}, w_{i}^{F}(\cdot)\right)-U_{i}^{E}\left(e_{i}=0, w_{j}, w_{i}^{F}(\cdot)\right) \geq 0,
$$

otherwise employees will work with normal work effort. Let $y^{H}=y\left(e_{i}=1\right)\left(y^{L}=y\left(e_{i}=0\right)\right)$ denote an employee's productivity when s/he exerts the high (normal) work effort. Then, the payoffs for the employees and employers simplifies to $\pi_{i}^{E}=w_{j}-c\left(e_{i}\right)$ and $\pi_{j}^{R}=y\left(e_{i}\right)-w_{j}$ respectively (see also above) so that $\Delta U_{i}^{E}$ can be determined with

$$
\Delta U_{i}^{E}=-\Delta c+\rho_{i}\left(w_{j}-w_{i}^{F}(\cdot)\right)\left(y^{H}-y^{L}\right),
$$

where $\Delta c=c\left(e_{i}=1\right)-c\left(e_{i}=0\right)>0$ is the difference in disutility that a high effort requires compared to a normal effort. Since $y^{H}-y^{L}$ as well as $\Delta c$ is positive, employees will work hard if

$$
w_{j} \geq \frac{\Delta c}{\rho_{i}\left(y^{H}-y^{L}\right)}+w_{i}^{F}\left(a_{i}, p_{i}\right)=: w_{i}^{H}\left(a_{i}, p_{i}\right)
$$

Therefore, an employee will only consider to work hard if the wage offer is sufficiently higher than the fair wage $w_{i}^{F}(\cdot)$.

$w_{i}^{F}$ and therefore $w_{i}^{H}$ are unknown to the employer. However, employers form beliefs about $w_{i}^{F}$ and therefore $w_{i}^{H}$ and are perfectly aware that the above inequality is more easily satisfied when the wage offer $w_{j}$ is higher. This result mirrors our Hypothesis 4 above. It is also obvious that higher levels of a fair compensation $w_{i}^{F}$ induce a lower work effort for every given wage offer $w_{j}$. This is expressed in our Hypothesis 5 above (see also Falk and Fischbacher, 2006).

To summarize, the optimal work effort is

$$
e_{i}^{*}= \begin{cases}1 & \text { if } w_{j} \geq w_{i}^{H}, \\ 0 & \text { if } w_{j}<w_{i}^{H} .\end{cases}
$$

\section{E.3. Employers' decision}

Employers are aware of the employees inclination to only work hard if the wage offer exceeds the employee's notion of a fair wage. However, employers have no way of ascertaining the level $w_{i}^{F}$ for an employee. Hence, the employer has to form beliefs about the employee's fair wage $w_{i}^{F}$ and $w_{i}^{H}$ on the basis of the employee's home province $p_{i}$. Unless the employer offers the maximum wage $w^{\max }$, there will always be a positive probability that the wage offer will be lower than the fair wage $w_{i}^{H}$ and that the employee exerts only the normal work effort. Consequently, employee $i$ 's productivity is uncertain as long as $w_{j}<w^{\max }$. Let $y^{H}$ and $y^{L}$ be defined as above. Then, the expected profits for employer $j$ can be written as

$$
\mathrm{E} \pi_{j}^{R}=F_{j}^{p_{i}}\left(w_{j} ; a_{i}\right)\left(y^{H}-w_{j}\right)+\left(1-F_{j}^{p_{i}}\left(w_{j} ; a_{i}\right)\right)\left(y^{L}-w_{j}\right) .
$$

Since $F_{j}^{p_{i}}\left(w_{j} ; a_{i}\right)$ denotes the probability that the fair wage $w_{i}^{F} \leq w_{j}$, employee $i$ will exert the high work effort and display the high productivity $y^{H}$. With the residual probability $1-F_{j}^{p_{i}}\left(w_{j} ; a_{i}\right)$ employee $i$ 's fair wage is higher than the wage offer $w_{j}$ so that employee $i$ will display the low productivity $y^{L}$.

Similar to employees, employers base their decision on the wage offer not exclusively on the expected profit. Employers might derive positive utility from being sympathetic to employees from the same province. Let $\mathbf{1}_{p_{j}}\left(p_{i}\right)$ denote the indicator function

$$
\mathbf{1}_{p_{j}}\left(p_{i}\right)= \begin{cases}1 & \text { if } p_{j}=p_{i} \in P, \\ 0 & \text { if } p_{j} \neq p_{i} \in P,\end{cases}
$$

i.e., the function takes the value one if the employee and the employer are from the same province and zero otherwise. 
Then, employer $j$ 's objective function is given by

$$
U_{j}^{R}=\mathrm{E} \pi_{j}^{R}+\alpha_{j} \mathbf{1}_{p_{j}}\left(p_{i}\right) w_{j}=F_{j}^{p_{i}}\left(w_{j} ; \cdot\right)\left(y^{H}-w_{j}\right)+\left(1-F_{j}^{p_{i}}\left(w_{j} ; \cdot\right)\right)\left(y^{L}-w_{j}\right)+\alpha_{j} \mathbf{1}_{p_{j}}\left(p_{i}\right) w_{j}
$$

where $\alpha_{j} \mathbf{1}_{p_{j}}\left(p_{i}\right) w_{j}$ is the utility that employer $j$ derives from paying an employee from the same home province as himself a higher wage.

An employer chooses $w_{j}$ so that his/her utility is maximized. The first and second order conditions are given by

$$
\begin{aligned}
& \frac{\partial U_{j}^{R}}{\partial w_{j}}=F_{j_{w j}}^{p_{i}}\left(w_{j} ; \cdot\right)\left(y^{H}-y^{L}\right)-1+\alpha_{j} \mathbf{1}_{p_{j}}\left(p_{i}\right) \leq 0, \\
& \frac{\partial^{2} U_{j}^{R}}{\partial w_{j}^{2}}=F_{j_{w j w j}}^{p_{i}}\left(w_{j} ; \cdot\right)\left(y^{H}-y^{L}\right) \leq 0 .
\end{aligned}
$$

Since $y^{H}-y^{L}$ is always positive, the second-order condition is only satisfied, if $F_{j_{w j w j}}^{p_{i}}\left(w_{j} ; \cdot\right) \leq 0$, i.e., if the employer offers a wage $w_{j}$ that is larger than his/her expectation of the fair wage $\mu_{j}^{p_{i}}$ for employee from province $p_{i}$. According to the firstorder condition, the optimal wage offer $w_{j}$ has to satisfy

$$
f_{j}^{p_{i}}\left(w_{j} ; \cdot\right)=\frac{1-\alpha_{j} \mathbf{1}_{p_{j}}\left(p_{i}\right)}{y^{H}-y^{L}}
$$

where $f_{j}^{p_{i}}\left(w_{j} ; \cdot\right)$ is the density function associated with the belief function $F_{j}^{p_{i}}\left(w_{j} ; \cdot\right)$.

\section{E.3.1. The optimal wage offer}

As previously discussed, the employer has to form beliefs about an employee's notion of a fair wage compensation on the basis of the only piece of information $s /$ he has - the home province $p_{i}$. We assumed that the belief functions $F_{j}^{p_{i}}\left(w_{j}\right.$; $\left.\cdot\right)$ are strictly unimodal with an expected value of $\mu_{j}^{p_{i}}$. Naturally, publicly available information about the provinces will influence the belief structure $\left\{F_{j}^{s}\right\}_{s \in P}$. It is reasonable to assume that the expected value $\mu_{j}^{p_{i}}$ equals the average wage in the province $p_{i}$. Then, it follows directly from the second-order condition above that the offered wage $w_{j}$ will be higher when the average wage $\mu_{j}^{p_{i}}$ increases, which is summarized in Hypothesis 1 above.

Since $f_{j_{w_{i}}}^{p_{i}}<0$ to satisfy the second-order condition, employers are prepared to pay higher wages to employees from their own home province according to Eq. (1). The stronger the attachment to their own province, i.e., the larger $\alpha_{j}$, the higher will be the wage offered to an employee from an employer's own home province. This is summarized in Hypothesis 2 above.

Finally, in Hypothesis 3 we state our belief that wage offers will decline as the shares of Non-Han Chinese in the employees' home province are increasing. Let $a_{i}$ stand for the share of Non-Han Chinese in $i$ 's home province $p_{i}$. From Eq. ( 1 ) follows immediately that the optimal wage offer changes with an increasing share of Non-Han Chinese according to

$$
\frac{d w_{j}}{d a_{i}}=-\frac{\partial f_{j}^{p_{i}}\left(w_{j} ; a_{i}\right) / \partial a_{i}}{\partial f_{j}^{p_{i}}\left(w_{j} ; a_{i}\right) / \partial w_{j}}<0 .
$$

The wage offer will decrease with an increasing share of Non-Han Chinese in the province if $\partial f_{j}^{p_{i}} / \partial a_{i}<0$. If the average wage is on average lower in provinces with a higher share on Non-Han Chinese which we indeed observe, then this condition will be satisfied.

\section{Appendix F. Supplementary data}

Supplementary data associated with this paper can be found in the online version at http://dx.doi.org/10.1016/j.euro ecorev.2016.04.005.

\section{References}

Akerlof, G.A., 1982. Labor contracts as partial gift exchange. Q.J. Econ., 543-569.

Akerlof, G.A., Yellen, J., 1990. The fair wage-effort hypothesis and unemployment. Q. J. Econ. 105 (2), $255-283$.

Akerlof, G.A., Kranton, R.E., 2000. Economics and identity. Q. J. Econ. 115 (3), 715-753.

Akerlof, G.A., Kranton, R.E., 2002. Identity and schooling: some lessons for the economics of education. J. Econ. Lit. 40 (4), $1167-1201$.

Akerlof, G.A., Kranton, R.E., 2008. Identity, supervision, and work groups. Am. Econ. Rev. 98 (2), $212-217$.

Åslund, O, Skans, O., 2012. Do anonymous job application procedures level the playing field? Ind. Labor Relat. Rev. 65, $82-107$.

Becker, G., 1957. The Economics of Discrimination. University of Chicago Press, Chicago.

Benjamin, D.J., Choi, J.J., Strickland, A.J., 2010. Social identity and preferences. Am. Econ. Rev. 100 (4), $1913-1928$.

Bertrand, M., Mullainathan, S., 2007. Are Emily and Greg more employable than Lakisha and Jamal? A field experiment on labor market discrimination. Am. Econ. Rev. 94 (4), 991-1013.

Büsch, V., Dahl, S.A., Dittrich, D.A.V., 2009. An empirical study of age discrimination in Norway and Germany. Appl. Econ. 41, 633-651.

Brown, M., Falk, A., Fehr, E., 2004. Relational contracts and the nature of market interactions. Econometrica 72 (3), $747-780$. 
Camerer, C.F., 2015. The promise and success of lab-field generalizability in experimental economics: a reply to Levitt and List. In: Frechette, G., Schotter, A.

(Eds.), The Methods of Modern Experimental Economics, Oxford University Press, Oxford.

Charness, G., Rustichini, A., 2011. Gender differences in cooperation with group membership. Games Econ. Behav. 72 (1), 77-85.

Charness, G., Kuhn, P., 2011. Lab labor: what can labor economists learn from the lab?, Handbook of Labor Economics4th edition. Elsevier.

Chen, R., Chen, Y., 2011. The potential of social identity for equilibrium selection. Am. Econ. Rev. 101 (6), 2562-2589.

Chen, Y., Li, S.X., 2009. Group identity and social preferences. Am. Econ. Rev. 99 (1), 431-457.

Chen, Y., Li, S.X., Liu, T.X., Shih, M., 2014. Which hat to wear? Impact of natural identities on coordination and cooperation. Games Econ. Behav. 84, 58-86.

Cohn, A., Fehr, E., Goette, L., 2014. Fair wages and effort provision: combining evidence from a choice experiment and a field experiment. Manag. Sci. 61 (8), $1777-1794$.

Cooper, D.J., Kagel, J.H., 2016. Other regarding preferences: a survey of experimental results. In: Kagel, J., Roth, A. (Eds.), The Handbook of Experimental Economics, vol. 2. Princeton University Press, Princeton, forthcoming.

Dollar, D., Jones, B.F., 2013. China: An Institutional View of an Unusual Macroeconomy. NBER Working Paper, 19662.

Du, Y., Park, A., Wang, S., 2005. Migration and rural poverty in China. J. Comp. Econ. 33 (4), 688-709.

Eckel, C.C., Grossman, P.J., 2005. Managing diversity by creating team identity. J. Econ. Behav. Organ. 58 (3), 371-392.

Falk, A., Fischbacher, U., 2006. A theory of reciprocity. Games and economic behavior, 54(2), 293-315.

Falk, A., Zehnder, C., 2013. A city-wide experiment on trust discrimination. J. Public Econ. 100, 15-27.

Fehr, E., Gächter, S., Kirchsteiger, G., 1997. Reciprocity as a contract enforcement device: experimental evidence. Econometrica 65 (4), $833-860$.

Fehr, E., Kirchler, E., Weichbold, A., Gächter, S., 1998. When social norms overpower competition: gift exchange in experimental labor markets. J. Labor Econ. 16 (2), 324-351.

Fershtman, C., Gneezy, U., 2001. Discrimination in a segmented society: an experimental approach. Q J. Econ. 116 (1), 351-377.

Fershtman, C., Gneezy, U., Verboven, F., 2005. Discrimination and nepotism: the efficiency of the anonymity rule. J. Legal Stud. 34(2), 371-396.

Gneezy, U., List, J.A., 2006. Putting behavioral economics to work: testing for gift exchange in labor markets using field experiments. Econometrica 74 (5), $1365-1384$.

Goerg, S.J., Kaiser, J., 2009. Nonparametric testing of distributions-the Epps-Singleton two-sample test using the empirical characteristic function. Stata J. 9 (3), 454-465.

Goerg, S.J., Kube, S., Zultan, R., 2010. Treating equals unequally: incentives in teams, workers' motivation, and production technology. J. Labor Econ. 28 (4), $747-772$.

Goette, L., Huffman, D., Meier, S., 2006. The impact of group membership on cooperation and norm enforcement: evidence using random assignment to real social groups. Am. Econ. Rev. 96 (2), 212-216.

Grimm, V., Mengel, F., 2009. Cooperation in viscous populations-experimental evidence. Games Econ. Behav. 66 (1), $202-220$.

Halevy, N., Bornstein, G., Sagiv, L., 2008. 'In-group love' and 'out-group hate' as motives for individual participation in intergroup conflict: a new game paradigm. Psychol. Sci. 19 (4), 405-411.

Hausman, D., 2012. How Congress could reduce job discrimination by promoting anonymous hiring. Stanf. Law Rev. 64 (5), $1343-1369$.

Herbst, D., Mas, A., 2015. Peer effects on worker output in the laboratory generalize to the field. Science 350 (6260), 545-549.

Kaiser, J., 2009. An exact and a Monte Carlo proposal to the Fisher-Pitman permutation tests for paired replicates and for independent samples. Stata J. 7 (3), 402-412.

Krause, A., Rinne, U., Zimmermann, K.F., 2012. Anonymous job applications of fresh Ph.D. economists. Econ. Lett. 117 (2), 441-444.

Kuhn, P., Shen, K., 2013. Gender discrimination in job ads: evidence from China. Q. J. Econ. 128 (1), 287-336.

Kuhn, P., Shen, K., 2014. Do Employers Prefer Undocumented Workers? Evidence from China's Hukou System. Working Paper.

Levitt, S.D., List, J.A., 2007. What do laboratory experiments measuring social preferences reveal about the real world? J. Econ. Perspect. 21 (2), $153-174$. Maximiano, S., Sloof, R., Sonnemans, J., 2007. Gift exchange in a multi-worker firm. Econ. J. 117 (522), 1025-1050.

Meng, X., Zhang, J., 2001. The two-tier labor market in urban China: occupational segregation and wage differentials between urban residents and rural migrants in Shanghai. J. Comp. Econ. 29 (3), 485-504.

Mobius, M.M., Rosenblat, T.S., 2006. Why beauty matters. Am. Econ. Rev. 96 (1), 222-235.

Neumark, D., Bank, R., Van Nort, K., 1996. Sex discrimination in restaurant hiring: an audit study. Q. J. Econ. 111, 915-941.

Pager, D., Western, B., Bonikowski, B. (2009). Discrimination in a low-wage labor market a field experiment. Am. Sociol. Rev, 74(5), 777-799.

Phelps, E.S., 1972. The statistical theory of racism and sexism. Am. Econ. Rev. 62 (4), 659-661.

Riach, Peter A., Judith Rich., 2010 An experimental investigation of age discrimination in the English labor market. Annals of Economics and Statistics/ Annales d'Économie et de Statistique, 169-185.

Selten, R., 1967. Die Strategiemethode zur Erforschung des eingeschränkt rationale Verhaltens im Rahmen eines Oligopolexperiments. In: Sauermann, Heinz (Ed.), Beiträge zur experimentellen Wirtschaftsforschung, Tübingen, pp. 136-68.

Sherif, C. W., Harvey, O. J., White, B. J., Hood, W. R. ,1961. Intergroup conflict and cooperation: The Robbers Cave Experiment , Vol. 10, University Book Exchange, Norman, OK, pp. 150-198.

Tajfel, H., Turner, J., 1979. An integrative theory of intergroup conflict. In: Worchel, Stephen, Austin, William (Eds.), The Social Psychology of Intergroup Relations. Brooks/Cole, Monterey, CA, pp. 33-47.

Wang, B., Li, X., Stanton, B., Fang, X., 2010. The influence of social stigma and discriminatory experience on psychological distress and quality of life among rural-to-urban migrants in China. Soc. Sci. Med. 71 (1), 84-92.

Wilson, R.K., Eckel, C.C., 2006. Judging a book by its cover: beauty and expectations in the trust game. Polit. Res. Q. 59 (2), 189-202.

Winter, E., 2004. Incentives and discrimination. Am. Econ. Rev. 94 (3), 764-773.

Yamagishi, T., Kiyonari, T. ,2000. The group as the container of generalized reciprocity. Soc.Psychol.Quart. 116-132.

Zhao, Y., 2003. The role of migrant networks in labor migration: the case of China. Contemp. Econ. Policy 21 (4), 1465-7287.

Zizzo, D.J., 2010. Experimenter demand effects in economic experiments. Exp. Econ. 13, 75-98.

Zussman, A., 2013. Ethnic discrimination: lessons from the Israeli online market for used cars. Econ. J. 123 (572), 433-468. 